\title{
Synthesis of Individual Proteins, Including Tubulins and Chloroplast Membrane Proteins, in Synchronous Cultures of the Eukaryote Chlamydomonas reinhardtii. Elimination of Periodic Changes in Protein Synthesis and Enzyme Activity under Constant Environmental Conditions
}

\author{
By M. J. ROLLINS, J. D. I. HARPER AND P. C. L. JOH N* \\ Department of Botany, The Queen's University, Belfast, BT7 INN, U.K.
}

(Received 13 October 1982; revised 1 December 1982)

\begin{abstract}
Chlamydomonas reinhardtii when growing under the conventional synchronizing conditions of batch culture and intermittent illumination shows periodic changes in the rate of ${ }^{35} \mathrm{SO}_{4}$ uptake and in the specific rate of ${ }^{35} \mathrm{~S}$ incorporation into protein relative to total protein. There are also periodic changes in the rates of synthesis of individual proteins including several chloroplast membrane proteins and of tubulin, which is synthesized maximally prior to the initiation of division events and is not synthesized during cytokinesis. Activities of citrate synthase and aspartate transcarbamoylase enzymes increase discontinuously under synchronizing conditions. These periodic events are not part of a developmental programme which is essential for division, since the periodicity disappears under constant environmental conditions. Synchronously dividing cells then show smoothly increasing rates of ${ }^{35} \mathrm{SO}_{4}$ uptake into cells and of incorporation into protein. There is a constant specific rate of isotope incorporation, relative to total protein, which correlates with the exponential accumulation of protein through the cell cycle. The 300 most abundantly labelled proteins are synthesized continuously through the cell cycle and this accords with the continuous accumulation of citrate synthase and aspartate transcarbamoylase enzyme activities. Tubulin synthesis is continuous under constant growth conditions and therefore periodic increases in tubulin concentration are not an essential part of mitotic spindle or phycoplast formation. Of the sedimentable proteins only one of the 200 most abundantly labelled shows a cessation of synthesis. A previously reported periodic synthesis of chloroplast membrane proteins is not essential for chloroplast assembly in dividing cells. The significance of these data is discussed in relation to cell cycle control and it is proposed that three categories of periodic event should be recognized. Periodic syntheses of proteins that are directly involved in division processes may be classed as primary cell cycle events if they accompany the cell cycle under all growth conditions, and these events may include division-initiating processes. If periodic synthesis of such proteins occurs only under some growth conditions then their synthesis is classed as a secondary cell cycle event. Discontinuous synthesis of proteins that do not contribute directly to division processes and are only synthesized discontinuously during or in recovery from changing environmental conditions, is considered a tertiary cell cycle event, but by adapting cell structure and metabolism to environmental conditions such events may indirectly sustain division processes. It is suggested that the periodic synthesis of tubulin under synchronizing conditions is consistent with the operation of a secondary cell cycle control, but that the periodic increases in the activity of a respiratory and biosynthetic enzyme and the periodic synthesis of numerous individual unidentified proteins, under changing conditions in synchronous culture are only tertiarily related to the cell cycle.
\end{abstract}

\section{INTRODUCTION}

The cell cycle has often been considered to involve synthesis of individual enzymes at different times (reviewed by Mitchison, 1969) and therefore to resemble other developmental 
processes in which numerous changes in enzyme synthesis and activity occur and may drive the process of differentiation (Hansen et al., 1970; Tuchman et al., 1974; Sussman \& Brackenbury, 1976; Linn \& Losick, 1976). Evidence for discontinuous increases of enzyme level in the cell cycle has come predominantly from synchronously dividing micro-organisms (Mitchison, 1971). Such evidence has been most extensive from Saccharomyces cerevisiae (Halvorson et al., 1971) but significant observations have also been made in unicellular algae, which can be sharply synchronized by diurnal cycles of periodic illumination (Lorenzen \& Hess, 1974), for example in Chlamydomonas (Kates \& Jones, 1967) and Chlorella (John et al., 1973; Schmidt, 1974). Discontinuous enzyme synthesis is also indicated by changes in the proteins that can be labelled under synchronizing conditions in Chlamydomonas (Howell et al., 1977).

However, the isolation of cell cycle mutants in Chlamydomonas by Howell's group (Howell \& Naliboff, 1973) allowed them to perform an experiment that led us to consider alternative interpretations of data from synchronized cells. When progress through the cell cycle was blocked in a mutant cell line, changes in protein synthesis that had been interpreted as part of a cell cycle programme were seen to continue (Howell et al., 1977). We concluded that the changes in protein synthesis were not dependent upon the completion of processes in the cell cycle and we therefore tested the possibility that they were not part of the cell cycle at all.

By studying the cell cycle under constant environmental conditions, as well as under the usual synchronizing conditions, we have shown that changes in the synthesis of proteins may be caused by the conditions of batch culture under periodic illumination. Many changes in the rate of accumulation of both protein and enzyme activity which accompany the cell cycle under changing environmental conditions, are neither caused by the cell cycle, nor are essential for cell division.

\section{METHODS}

Organism and culture medium. The alga Chlamydomonas reinhardtii $137 \mathrm{c} \mathrm{mt^{+ }}$ was grown photoautotrophically in a mineral salts medium, based on the High Salt Mineral medium of Sueoka et al. (1967) which contained, per litre oi glass-distilled water: $0.5 \mathrm{~g} \mathrm{NH}_{4} \mathrm{Cl}, 0.01 \mathrm{~g} \mathrm{CaCl}_{2} .2 \mathrm{H}_{2} \mathrm{O}, 1.44 \mathrm{~g} \mathrm{~K}_{2} \mathrm{HPO}_{4}, 0.72 \mathrm{~g} \mathrm{KH}_{2} \mathrm{PO}_{4}$. The medium was modified in the manner of Lien \& Knutsen (1976) by supplying iron as an Fe-EDTA complex which contributed $6.9 \mathrm{mg} \mathrm{FeSO}+7 \mathrm{H}_{2} \mathrm{O}$ and $9.3 \mathrm{mg} \mathrm{Na}{ }_{2}$ EDTA per litre. Trace elements were supplied at the concentrations proposed by $\mathrm{Kuhl} \&$ Lorenzen (1964). The medium was usually made $0.83 \mathrm{~mm}$ with respect to sulphate, by the addition of $0.2 \mathrm{~g} \mathrm{MgSO}_{4} .7 \mathrm{H}_{2} \mathrm{O}$ per litre to supplement the $0.02 \mathrm{mM}$-sulphate from the trace elements solution. The $\mathrm{pH}$ after autoclaving was $7 \cdot 0$. Stock cultures were maintained on medium containing $1.2 \%(\mathrm{w} / \mathrm{v})$ agar and $0.5 \%$ $(\mathrm{w} / \mathrm{v})$ glucose and on this solidified medium, cells were streaked out to form clones. When higher specific radioactivities were required, a low sulphate medium of $0.07 \mathrm{~mm}$ total sulphate concentration was employed and this contained $0.0125 \mathrm{~g} \mathrm{MgSO}_{4} .7 \mathrm{H}_{2} \mathrm{O}$ per litre, with magnesium levels maintained at $0.81 \mathrm{~mm}$ by the addition of $0 \cdot 155 \mathrm{~g} \mathrm{MgCl}_{2} .6 \mathrm{H}_{2} \mathrm{O}$ per litre.

Induction of synchrony. Synchronous division was induced in 2.5 litre batch cultures, $70 \mathrm{~mm} \times 150 \mathrm{~mm} \times$ height $238 \mathrm{~mm}$, that were maintained at $25^{\circ} \mathrm{C}$ and aerated with sterile moistened air containing $0.5 \%(\mathrm{v} / \mathrm{v}) \mathrm{CO}_{2}$. Cultures received illumination on both long sides of the vessel from banks of warm-white fluorescent lights, giving $140 \mu \mathrm{E} \mathrm{m}^{-2} \mathrm{~s}^{-1}$ in the range $400-700 \mathrm{~nm}$ at the surface of the vessel. Cycles of $14 \mathrm{~h}$ illumination and $10 \mathrm{~h}$ darkness were employed and cultures were diluted at the end of each dark period to a turbidity $A_{680.1 \mathrm{~cm}}$ of 0.06 , giving a daughter cell density of $10^{6} \mathrm{ml}^{-1}$. Ten such cycles were employed to achieve full synchronization before cultures were analysed.

Maintenance of synchronous division under constant illumination in a turbidostat. Constant environmental conditions were provided by turbidostat growth in 10 litre cultures of $70 \mathrm{~mm} \times 600 \mathrm{~mm} \times$ height $238 \mathrm{~mm}$. These cultures therefore had the same breadth for light penetration as the synchronizing cultures and the light available to individual cells was held constant. Illumination was continuous and changes in mutual shading were eliminated by inflow of fresh medium at $25^{\circ} \mathrm{C}$ which held turbidity constant. Medium was admitted automatically when growth of the culture created an imbalance between the illumination of a photocell receiving light through the culture and a reference photocell. This form of culture was first used by Myers \& Clark (1944) to provide a continuous source of physiologically reproducible cells. By automatic monitoring of medium consumption we extended the use of turbidostat culture to study growth throughout the cell cycle. For this purpose the extent of dilution that had been necessary to maintain turbidity up to each sample time was calculated, taking into account phases when the culture was recovering its volume after sampling (Herbert et al., 1956). Data presented here for turbidostat cultures have been corrected for culture dilution. They display growth directly and show the increases 
in parameters as they would have been observed in batch culture if effects of increasing turbidity could have been eliminated.

Cell number. Cell number was estimated after fixing cells with $0.25 \%$ formaldehyde, by counting with a haemocytometer or with a Coulter Counter, model ZB. Except where otherwise stated, cells were scored as separate only after release from mother cell envelopes.

DNA estimation. DNA was estimated by the diphenylamine method (Hopkins et al. 1972).

Incubation of cells with radioactive isotope. Precautions were taken to minimize physiological disturbance during pulse labelling with ${ }^{35} \mathrm{SO}_{4}$. Carrier-free ${ }^{35} \mathrm{SO}_{4}$ was added to cells that were transferred, without centrifugation or other pause, into a subculture of $70 \mathrm{~mm} \times 70 \mathrm{~mm} \times$ height $238 \mathrm{~mm}$ that was located beside the parent culture and was illuminated and aerated in parallel. Growth was therefore continued during labelling without interruption or change in light intensity. Labelling periods were one eighth of the cell cycle in duration. Cycle time was $24 \mathrm{~h}$ under synchronizing periodic illumination but in continuous light the initiation of cycle-controlling timers was not delayed and cycle duration was $20 \mathrm{~h}$ (Donnan \& John, 1983). Therefore corresponding labelling periods under the two culture conditions were 3 and $2.5 \mathrm{~h}$, respectively. In experiments to compare rates of assimilation throughout the cell cycle, high sulphate medium was employed. This provided more than 30 times the requirement for sulphate in a cell cycle and therefore specific radioactivity was essentially constant in successive labelling periods.

Cell breaking and fractionation. Cells were harvested by centrifugation for $1 \mathrm{~min}$ at $5000 \mathrm{~g}$ and the supernatant was sampled to determine residual unabsorbed isotope. The cells were then washed by resuspension in $50 \mathrm{~mm}-$ Tris $/ \mathrm{HCl} \mathrm{pH} 7.4$ at $0{ }^{\circ} \mathrm{C}$, immediately repelleted and resuspended in $10 \mathrm{ml}$ of the same buffer and then passed at $0{ }^{\circ} \mathrm{C}$ through a French pressure cell at $17.5 \mathrm{~kg} \mathrm{~mm}^{-2}$. The emerging broken cells passed directly through a $400 \mathrm{~mm}$ length of $1 \mathrm{~mm}$ diameter stainless steel tubing in ice and were collected at $0{ }^{\circ} \mathrm{C}$. The resulting cell extract was immediately sampled for the determination of total isotope taken up, for assay of enzyme activity and, by precipitation with TCA, for estimation of total protein content and assay of isotope incorporation into protein. For electrophoresis, fresh cell extract was centrifuged immediately at $500000 \mathrm{~g}$ for $20 \mathrm{~min}$ to obtain a post-ribosomal supernatant (termed the soluble fraction) and a pellet (termed the sedimentable fraction) which were stored at $-20^{\circ} \mathrm{C}$. Presence of the proteinase inhibitor phenylmethylsulphonyl fluoride in the extraction buffer had no effect on electrophoretic patterns but immediate cell smash and centrifugation to obtain the soluble fraction was essential for good resolution by two-dimensional electrophoresis.

Protein assay. Protein was precipitated with $5 \%(\mathrm{w} / \mathrm{v}) \mathrm{TCA}$, then dissolved in $0.2 \mathrm{M}-\mathrm{NaOH}$ and assayed by the Lowry method.

Enzyme assays. Broken cell suspension was clarified by centrifugation at $1000 \mathrm{~g}$ for $1 \mathrm{~min}$ to remove cell wall debris before estimation of enzyme activity.

Aspartate transcarbamoylase (EC 2.1.3.2) activity was assayed by the method of Gerhart \& Pardee (1962). The reaction at $28^{\circ} \mathrm{C}$ was started by the addition of $0.2 \mathrm{ml}$ cell-free extract, diluted to contain between 15 and $40 \mu \mathrm{g}$ protein, to maintain the rate of reaction within the range of linear response to enzyme. The reaction was stopped after $30 \mathrm{~min}$ by the addition of the $\mathrm{H}_{2} \mathrm{SO}_{4}$, diacetylmonoxime and diphenylamine sulphonate reagent mixture, described by Gerhart $\&$ Pardee (1962). Standards containing up to $0.5 \mu$ mol carbamyl aspartate were processed in parallel and the absorbance was read $20 \mathrm{~min}$ after addition of the final reagent.

Citrate synthase (EC 4.1.3.7) activity was assayed by the method of Cooper \& Beevers (1969). Assays contained between 15 and $40 \mu \mathrm{g}$ cell-free extract to maintain the rate of reaction within the range of linear response to the amount of enzyme. The reaction at $30^{\circ} \mathrm{C}$ was started by addition of acetyl-CoA to $0 \cdot 12 \mathrm{~mm}$ and the initial rate of CoA-DTNB complex formation was followed at $412 \mathrm{~nm}$.

Assay of isotope incorporation into protein. Incorporation was estimated after precipitation with carrier according to the method of O'Farrell (1975).

One-dimensional electrophoresis. Samples of post-ribosomal supernatant or of sedimented proteins were precipitated and suspended in $90 \%(\mathrm{w} / \mathrm{v})$ acetone. The procedure was repeated at least twice and continued until no pigment colour remained. The protein was dissolved at 5 to $10 \mathrm{mg} \mathrm{ml}^{-1}$ in dissociating buffer containing $30 \%$ $(\mathrm{w} / \mathrm{v}) 2$-mercaptoethanol, $10 \%(\mathrm{w} / \mathrm{v})$ sodium lauryl sulphate, $10 \%(\mathrm{w} / \mathrm{v})$ glycerol, $62.5 \mathrm{~mm}$-Tris/ $\mathrm{HCl} \mathrm{pH} 6.8$ and $0.001 \%$ bromophenol blue. The samples were incubated in a boiling water bath for $4 \mathrm{~min}$, cooled in ice and then between 50 and $200 \mu \mathrm{g}$ protein was subject to electrophoresis by the method of Laemmli (1970). Electrophoresis in a $100 \mathrm{~mm} \times 170 \mathrm{~mm} \times 0.75 \mathrm{~mm}$ slab gel was carried out at $10 \mathrm{~mA}$ constant current.

Copolymerization with porcine brain tubulin. Tubulin was purified from brains of freshly slaughtered pigs by three cycles of assembly triggered by warmth, magnesium, GTP and high glycerol concentration, as described by Weingarten et al. (1974). Purified tubulin was stored frozen and before use was subject to a further cycle of repolymerization. Extracts of Chlamydomonas protein for copolymerization were prepared by breaking cells suspended in the lysis buffer of Baum et al. (1978) at $4{ }^{\circ} \mathrm{C}$ in a French pressure cell. Extracts were clarified by centrifugation and subject to copolymerization with a threefold excess by weight of brain tubulin as described by Baum et al. (1978). Four cycles of polymerization and depolymerization were performed. Contamination of copolymerizing Chlamydomonas tubulin with a protein, identified as ribulose-1,5-bisphosphate carboxylase 
oxygenase (EC 4.1.1.4) from the migration in two-dimensional separations of its component large and small subunits, could not be reduced by further cycles of repolymerization, by freezing of the extract prior to copolymerization, or by use of a higher ratio of brain to algal protein.

Deflagellation and detection of tubulin synthesis. Cells growing in low sulphur medium and at $1 \mathrm{~h}$ in the synchronizing cycle (as in Fig. 1) were pelleted by brief centrifugation at $2000 \mathrm{~g}$, washed and resuspended in the sulphur-free medium of Weeks \& Collis (1979) and allowed to resume autotrophic growth for $1 \mathrm{~h}$ to deplete nonradioactive sulphate. The culture was divided and a $100 \mathrm{ml}$ volume was subject to deflagellation according to the method of Witman et al. (1972) by addition of $0.5 \mathrm{M}$-acetic acid with vigorous stirring to $\mathrm{pH} 4.5$. After $30 \mathrm{~s}, \mathrm{pH} \mathrm{7.0}$ was restored by addition of $\mathrm{KOH}$, the cells were diluted with $400 \mathrm{ml}$ of fresh sulphur-free medium and $1 \cdot 7 \mu \mathrm{Ci}$ $(62.9 \mathrm{kBq}) \mathrm{ml}^{-1}$ of carrier-free ${ }^{35} \mathrm{SO}_{4}$ was added. The cells were returned to autotrophic growth conditions and regeneration of flagella was observed during the subsequent $2 \mathrm{~h}$, at the end of which period the cells were harvested and broken for electrophoresis.

Two-dimensional electrophoresis. Samples containing $100 \mu \mathrm{g}$ protein were precipitated with $90 \%(\mathrm{v} / \mathrm{v})$ acetone and the protein was recovered by centrifugation in a tapered microcentrifuge tube at $5000 \mathrm{~g}$ for $5 \mathrm{~min}$. The protein was vigorously resuspended in fresh $90 \%(\mathrm{v} / \mathrm{v})$ acetone and was repelleted. This procedure was repeated until the sample was colourless; it was then dissolved in $0.2 \mathrm{ml}$ of dissociating buffer and was heated and treated with urea as described by Lutkenhaus et al. (1979). Ampholines (from LKB) were added according to O'Farrell (1975) and $20 \mu \mathrm{g}$ protein was subjected to isoelectric focusing. Gels were then stored at $-20^{\circ} \mathrm{C}$ before equilibration and electrophoresis in the second dimension, essentially as described by O'Farrell (1975). Internal standards of $\mathrm{pH}$ in the focusing dimension were provided by C-phycocyanin from Anacystis nidulans, pI 4.7; Azurin from Pseudomonas aeruginosa, pI 5.65; ovotransferrin from hen eggs, pI 6.05; all purchased from BDH.

Detection of radioactive proteins after electrophoresis. Gels were immersed in $20 \%$ (w/v) TCA overnight and then prepared for fluorography, by dehydration and impregnation with PPO, by the method of Laskey \& Mills (1975). The gels were dried on to Whatman $3 \mathrm{MM}$ chromatography paper and exposed directly on to Kodak Blue Brand $\mathrm{X}$-ray film which had been pre-exposed by flash. Exposure was performed at $-70^{\circ} \mathrm{C}$.

\section{RESULTS}

Two different culture conditions were employed. One form of culture was the commonly used synchronizing regime for algae, in which a batch culture was subjected to diurnal cycles of light and dark with a dilution in the dark period (Kuhl \& Lorenzen, 1964), while the other form of culture allowed cells to progress through the cell cycle under constant environmental conditions by transfer of synchronized cells to continuous illumination in a turbidostat.

\section{Protein and enzyme synthesis under periodic illumination}

In the synchronizing regime the period of darkness halts autotrophic growth (Fig. 1). Under these conditions citrate synthase activity showed changes in rate of accumulation through the cell cycle and increased more rapidly after $9 \mathrm{~h}$ (Fig. $2 a$ ). There was a consequent decline in specific activity early in the cell cycle and subsequently an increase (Fig. $2 b$ ). Accumulation of aspartate transcarbamoylase activity also changed, accelerating after $12 \mathrm{~h}$ (Fig. $2 c$ ) with consequent increase in specific activity after that time (Fig. $2 d$ ). Both enzymes showed more than threefold changes in their activity relative to the content of other protein in the cells.

Isotope uptake and incorporation also indicated that physiological changes occur during the cell cycle under synchronizing conditions. The uptake of ${ }^{35} \mathrm{SO}_{4}$ and its incorporation into protein were maximal at the end of the light period (Fig. $3 a$ ). After darkening there was a decline of both rates to one third or less, which correlated with the deprivation of energy for biosynthesis. No balance between cell growth and rates of uptake and incorporation was reached in the illuminated period, since the rates of uptake and incorporation increased by a factor of only two in this period while the cells had grown sevenfold in protein content and there was therefore a decline in rate of specific incorporation throughout the cell cycle (Fig. $3 a$ ). However specific radioactivity was essentially constant in successive pulses throughout the cell cycle, since total uptake overall was less than $3 \%$ and depletion of sulphate prior to each pulse was therefore not significant.

Physiological changes under synchronizing conditions were also reflected in the rate of synthesis of individual proteins. Rates of synthesis were studied by pulse labelling with ${ }^{35} \mathrm{SO}_{4}$ for successive $3 \mathrm{~h}$ periods throughout the cell cycle under synchronizing conditions. The proteins 


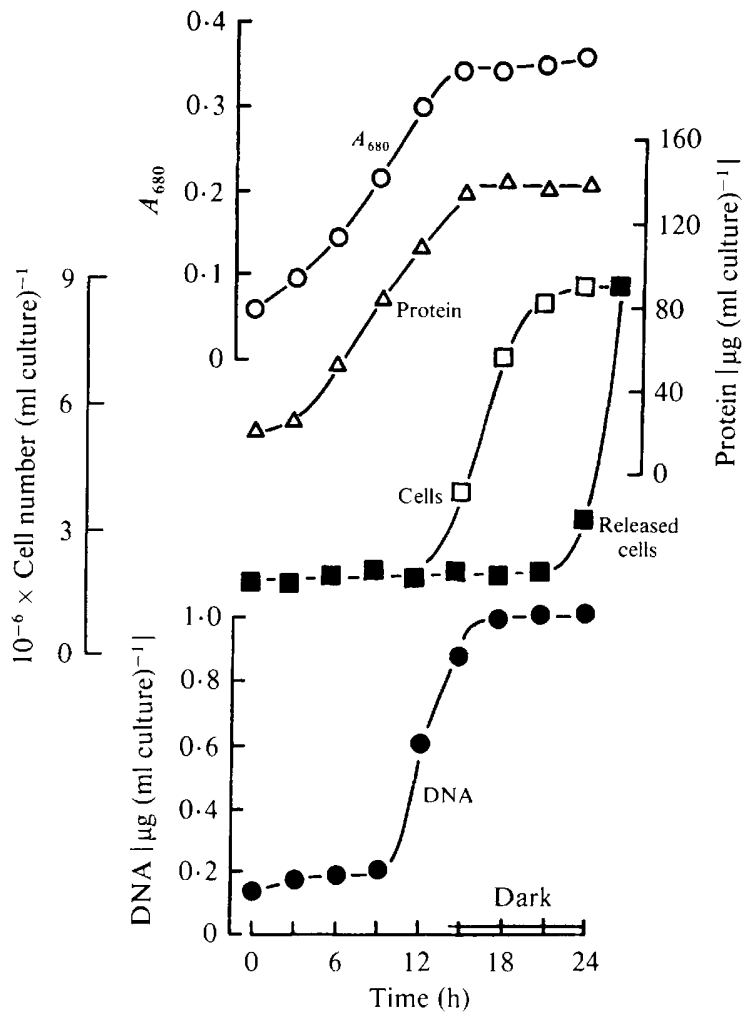

Fig. 1. Growth observed under synchronizing conditions in batch culture. Cells were illuminated from 0 to $14 \mathrm{~h}$ and were in darkness from 14 to $24 \mathrm{~h}$. The culture was analysed for: turbidity at $680 \mathrm{~nm}$ in a $10 \mathrm{~mm}$ cuvette $(O)$, measured with a PYE SP800 spectrophotometer in the close sample position which is least affected by light scattering; total protein precipitated by $5 \%(\mathrm{w} / \mathrm{v})$ TCA from broken cell extract $(\triangle)$; number of cells $(\boldsymbol{\square})$; number of cells including unreleased daughter cells $(\square)$ and DNA $(\boldsymbol{O})$.

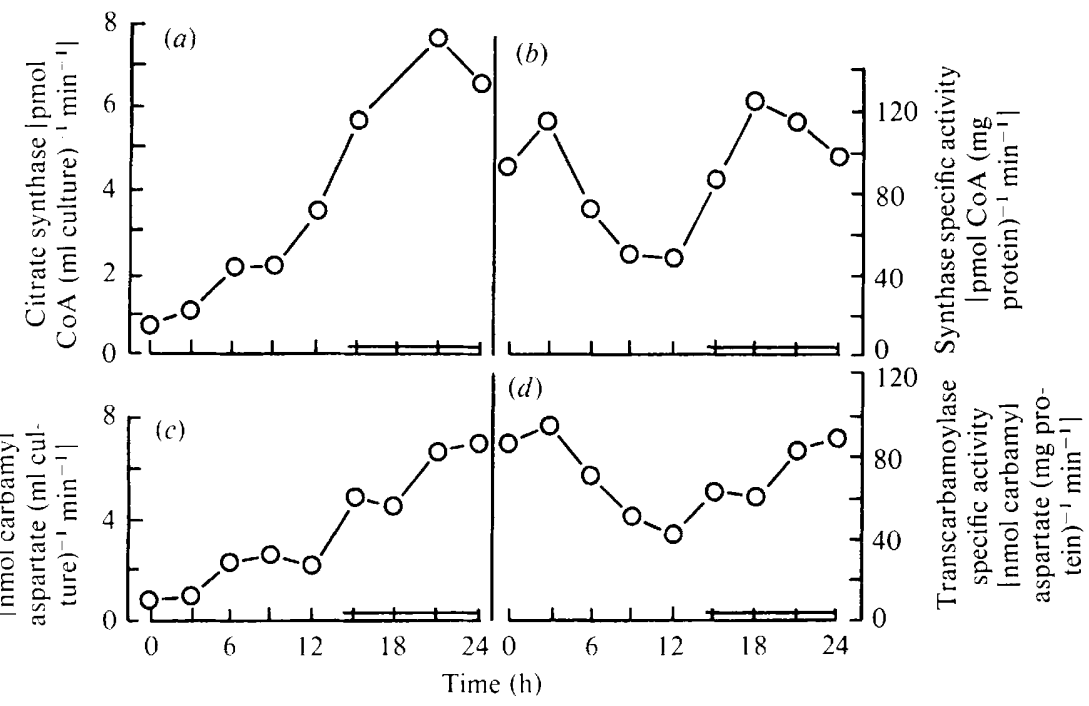

Fig. 2. Enzyme activity under the synchronizing growth conditions shown in Fig. 1. Enzymes were assayed in extracts of broken cells and are: $(a)$ citrate synthase activity ( $\mathrm{ml}$ culture $)^{-1}(b)$ citrate synthase specific activity; (c) aspartate transcarbamoylase activity ( $\mathrm{ml}$ culture $)^{-1}$ and (d) aspartate transcarbamoylase specific activity. Specific activities are relative to total protein shown in Fig. 1. 

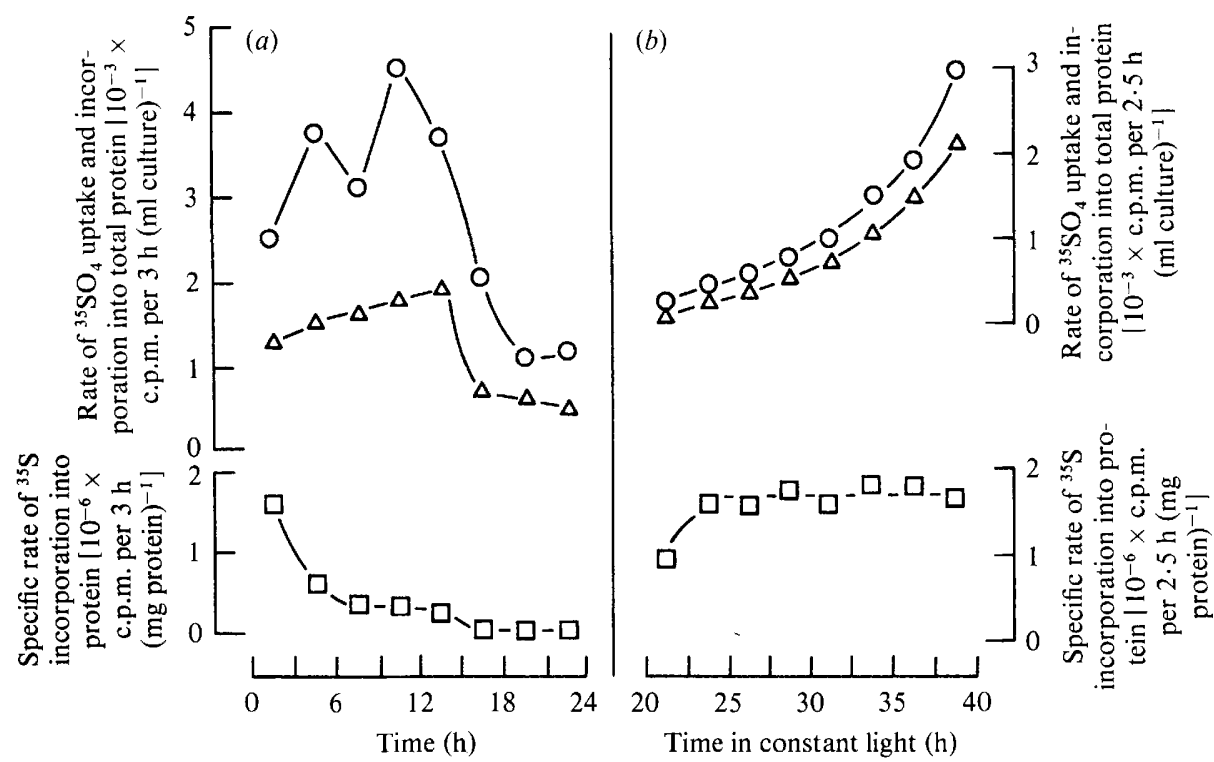

Fig. 3. Uptake and incorporation into protein, of ${ }^{35} \mathrm{SO}_{4}$ in successive periods of pulse labelling $(a)$ by cells under synchronizing conditions in batch culture darkened at $14 \mathrm{~h}$ and $(b)$ by cells undergoing their second cell cycle under constant environmental conditions in turbidostat. Times of cell cycle events in $(a)$ are shown in Fig. 1 and for $(b)$ in Fig. 7. Both cultures contained high sulphur medium of $0.83 \mathrm{~mm}-$ $\mathrm{SO}_{4}$ and samples from both were pulse labelled by decanting cells in their original growth medium into subcultures where they immediately received carrier free ${ }^{35} \mathrm{SO}_{4}$ and were cultured in parallel with the parent culture without interruption of growth or change in culture conditions. In both cultures $(a)$ and (b) the periods of pulse labelling were of one eighth of a cell cycle in duration. In (a) subcultures were set up at $3 \mathrm{~h}$ intervals, received $0.38 \mu \mathrm{Ci}^{35} \mathrm{SO}_{4} \mathrm{ml}^{-1}$ and were maintained for $3 \mathrm{~h}$. In $(b)$ subcultures were set up at $2.5 \mathrm{~h}$ intervals, received $0.34 \mu \mathrm{Ci}^{35} \mathrm{SO}_{4} \mathrm{ml}^{-1}$ and were maintained for $2.5 \mathrm{~h}$. After pulse labelling cells were harvested and smashed and estimates made of: total sulphate taken up $(O)$; sulphate incorporated into total protein and recovered in a precipitate formed by $5 \%(w / v)$ TCA $(\triangle)$. Rates of uptake and incorporation are plotted at the mid-time of the pulse periods. Also shown $(\square)$ is the specific rate of incorporation into protein relative to the total protein present in the same culture at mid-pulse, in (a) taken from the line for protein shown in Fig. 1, in $(b)$ taken from estimates of protein not shown, but similar to those in Fig. 7, which describes a culture in low sulphur medium. In $(b)$ amounts of uptake and incorporation have been multiplied by the growth factor (as explained in Fig. 7) to demonstrate the pattern of increase throughout the cell cycle, however in the text, for calculation of sulphate depletion, a direct comparison is made between counts supplied and those taken up (without multiplication of both by growth factor).

recovered in the supernatant (Fig. 4) and sedimentable (Fig. 5) fractions were subject to onedimensional electrophoresis under dissociating conditions and numerous fluctuations in the rate of isotope incorporation through the cell cycle were revealed.

Of the abundant soluble proteins, 18 showed marked changes in rate of synthesis (Fig. 4) and of the abundant sedimentable proteins, 26 also showed clear changes of synthesis (Fig. 5). A total of about 100 bands was resolved in the two fractions and therefore more than a third of these showed large periodic changes in rate of synthesis. A similar incidence of periodicity was observed by Howell et al. (1977), also after one-dimensional separation.

\section{Identification of tubulins and their synthesis under periodic illumination}

Some of the abundant proteins separated could be identified as specific cellular components and therefore an indication of their rate of synthesis through the cell cycle was obtained. We identified tubulin by in vitro copolymerization with brain tubulin (Fig. 6) and by the in vivo induction of its synthesis after deflagellation (Fig. 12). The proteins that repeatedly copolymerized with brain tubulin can be seen in Fig. 6, electrophoresed in parallel with the total 


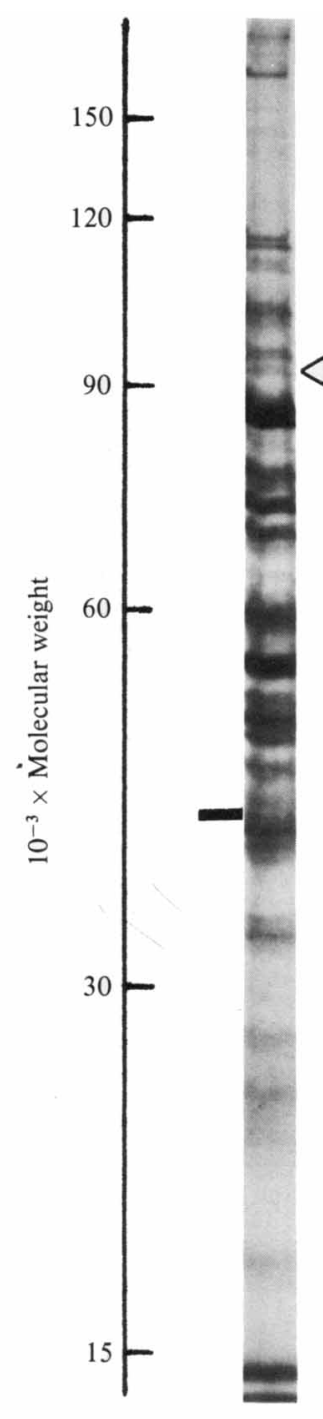

0

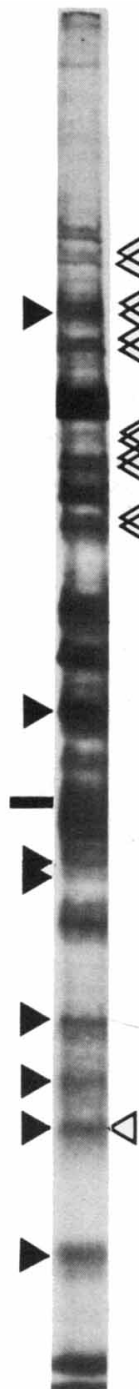

3

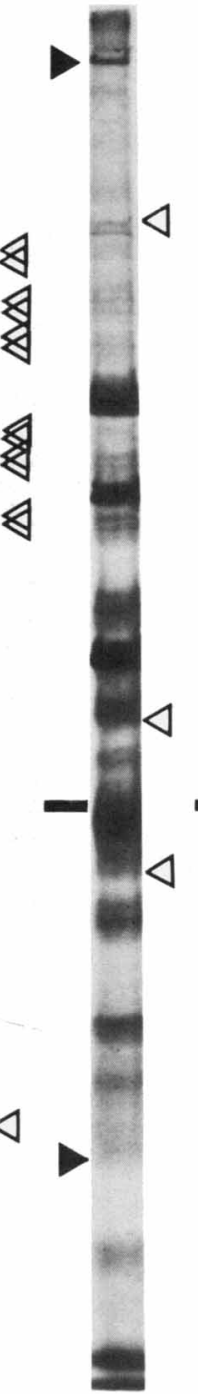

6

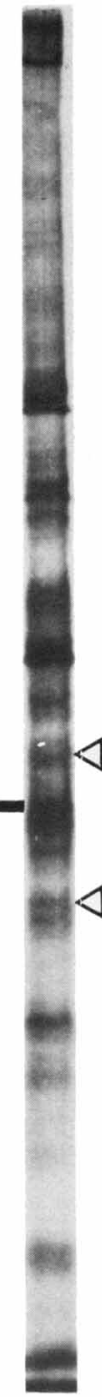

9

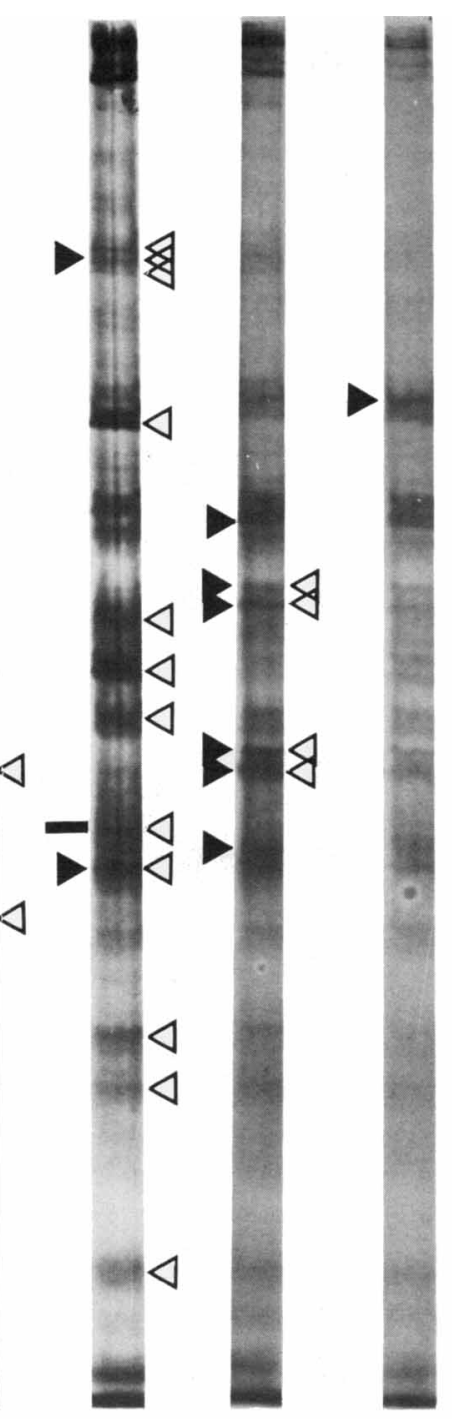

12

15

18

Fig. 4. Soluble proteins synthesized under synchronizing growth conditions during successive $3 \mathrm{~h}$ periods of labelling with ${ }^{35} \mathrm{SO}_{4}$, by cells which were pulse labelled as in Fig. 3(a) except that the cells were grown throughout in low sulphur medium of $0.07 \mathrm{~mm}-\mathrm{SO}_{4}$. Protein obtained from smashed cells was centrifuged at $500000 \mathrm{~g}$ for $20 \mathrm{~min}$ to obtain a sedimentable and a soluble fraction. Proteins were dissociated under reducing conditions and $100 \mu \mathrm{g}$ samples were subjected to one-dimensional electrophoresis with a $15 \%(\mathrm{w} / \mathrm{v})$ acrylamide separating gel according to the method of Laemmli (1970) and were detected by fluorography. Similar amounts of radioactivity were loaded in each track, therefore rates of total protein synthesis through the cell cycle (Fig. $3 a$ ) are not indicated but relative rates of individual protein synthesis are evident. Proteins which show abrupt increases $(\rightarrow$ or decreases $(\checkmark)$ in rate of incorporation of isotope in the subsequent pulse labelling period are indicated, and tubulin is marked $(\square)$.

soluble protein population from which they were derived. After four cycles of depolymerization and repolymerization only two proteins from Chlamydomonas were seen to associate persistently with porcine brain tubulin. One of these was ribulose-1,5-biphosphate carboxylase oxygenase 


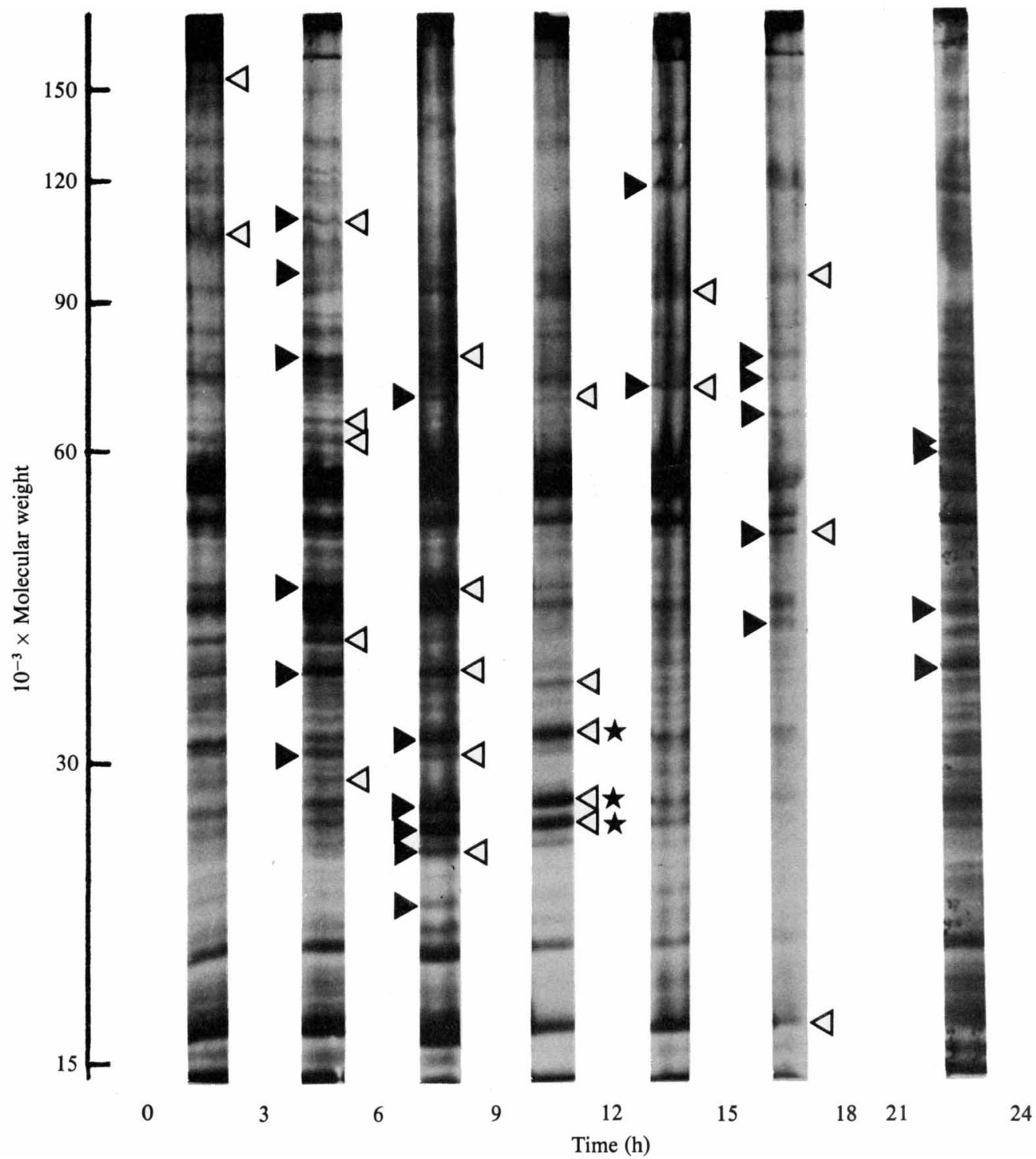

Fig. 5. Proteins in the sedimentable fraction synthesized in successive $3 \mathrm{~h}$ periods of pulse labelling under synchronizing conditions. The proteins sedimented in $20 \mathrm{~min}$ at $500000 \mathrm{~g}$, as described in Fig. 4 , were acetone extracted as described in Methods and were electrophoresed as in Fig. 4. Proteins showing abrupt changes in rate of synthesis are indicated as in Fig. 4 and chloroplast membrane proteins of group IIb and IIc are shown by the stars.

(RUBISCO) which was identified by the presence of its component large (L) subunit, mol. wt 56000 and small (S) subunit, mol. wt 14000 (Fig. 6) both of which proteins focused at a pI of 6.5 and so were remote from the tubulins, which were at $\mathrm{pH} 5.4$ and 5.6 (Fig. 11). It may be significant that RUBISCO, like tubulin, is a polymer of heterodimers and is capable of forming linear associations (Haselkorn et al., 1965; Gunning et al., 1968) but whether it was intercalated into the polymerized tubules is unknown. The central band among the proteins which repeatedly copolymerize with brain tubulin (Fig. 6), was identified as containing tubulins because of its repeated copolymerization and electrophoretic and isoelectric focusing properties. Our onedimensional electrophoresis conditions did not resolve the $\alpha$ and $\beta$ subunits of tubulin and such 


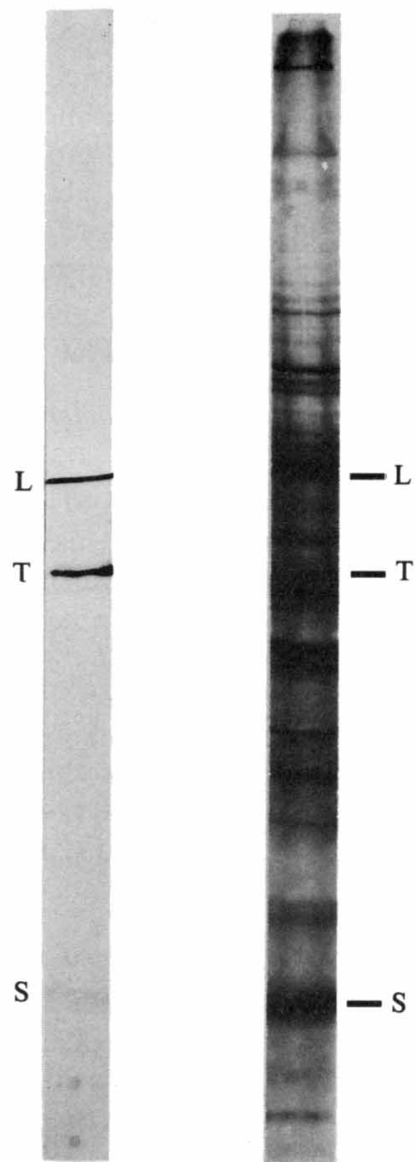

Fig. 6. Copolymerization of ${ }^{35} \mathrm{~S}$-labelled Chlamydomonas proteins with porcine brain tubulin. Shown in (a) are radioactive proteins which copolymerized with brain tubulin through four cycles of assembly and disassembly and in $(b)$ total soluble proteins that were mixed with brain tubulin in the ratio $1: 3$ $(w / w)$ before the first polymerization. T, tubulin; $L, S$, proteins identified as large and small subunits of ribulose-1,5-bisphosphate-carboxylase oxygenase from their mobilities on two-dimensional separations compared with known Chlamydomonas enzyme, run in parallel. To obtain radioactive proteins, cells in mid Gl phase as in Fig. 4 were transferred to sulphur-free medium for $1 \mathrm{~h}$, prior to a $2 \mathrm{~h}$ period of labelling with carrier-free ${ }^{35} \mathrm{SO}_{4}$ at $2 \mu \mathrm{Ci} \mathrm{ml}{ }^{-1}$. Electrophoresis was performed as in Figs 4,5 and 9 . The special conditions of low acrylamide concentration (Brunke et al., 1982) and impure SDS (Best et al., 1981) necessary to resolve $\alpha$ and $\beta$ tubulin subunits in one-dimensional separation were not adopted therefore tubulins are seen as a single band.

resolution was theoretically not to be expected in dissociating gels since the two subunits are both of mol. wt 50000 and have $40-50 \%$ amino acid sequence homology (Postingl et al., 1981; Valenzuela, 1981). Both Chlamydomonas tubulin subunits were, however, present in the copolymerized tubulin since they could be resolved by two-dimensional electrophoresis (not shown, but location of tubulins identical with that in Fig. 12) and they then revealed pI values of 5.4 and 5.6, which correlated with those reported for Chlamydomonas $\beta$ and $\alpha$ tubulins, respectively (Lefebvre et al., 1980) and also with the position of the tubulins induced by deflagellation when subject to the same separation (Fig. 12).

The position of tubulins among the separated soluble proteins labelled during the cell cycle is marked in Fig. 4. The pattern of incorporation of label was consistent with the changes of tubulin level through the cell cycle which were reported in this strain of Chlamydomonas under synchronizing periodic illumination by Piperno \& Luck (1977). Concentrations of tubulin were 
reported to increase in late $\mathrm{G} 1$ and then to decline from $15 \mathrm{~h}$, when mitoses were finishing and the protein was completing its functions for the current cell cycle. The present study correlated with these changes in tubulin level since incorporation into proteins migrating to the position occupied by tubulins, formed a low proportion of total protein synthesis in early G1 but then increased and remained at a high level until $15 \mathrm{~h}$ when tubulin synthesis was no longer evident (Fig. 4). Absence of tubulin synthesis in early G1 was more rigorously demonstrated by the twodimensional fractionation in Fig. 12, which showed that tubulin synthesis was not detectable early in G1 phase under synchronizing conditions unless induced by deflagellation. Similar high rates of tubulin synthesis in mid and late Gl phases were noted by Weeks \& Collis (1979).

\section{Chloroplast membrane protein synthesis under periodic illumination}

Proteins in the sedimentable fractions also provide evidence for periodic synthesis of known cellular components. The chloroplast occupies close to $40 \%$ of cell volume in Chlamydomonas (Schötz et al., 1972) and its thylakoid membranes make the major contribution to the sedimentable protein fraction. In this fraction the prominent proteins of mol. wt 31000 and the doublet of proteins close to $27000 \mathrm{~mol}$. wt which were predominantly synthesized in mid cycle between $6 \mathrm{~h}$ and $12 \mathrm{~h}$ (Fig. 5), corresponded to the abundant chloroplast proteins classified in Chlamydomonas as IIb and IIc by Beck \& Levine (1974) and as proteins M4 and M5 by Bourguignon \& Palade (1976). The IIb proteins are now known to be nuclear coded components of light harvesting complex 2 and of photosystem II (Wollman et al., 1980) and the IIc protein, also nuclear coded, is the major protein of the light harvesting complex (Hiller \& Goodchild, 1981). Their pattern of synthesis under our growth conditions being restricted to mid G1 phase coincided exactly with that described by Beck \& Levine (1974).

\section{Test for environmental effects by transfer to constant growth conditions}

To test whether the changes in rates of specific uptake and incorporation into total protein and the programme of individual protein synthesis were caused by the cell cycle, synchronized cells were transferred to stable environmental conditions in a turbidostat. Synchronous division persisted, with gradually declining precision, for at least three cell cycles under these conditions. We learned from similar studies in Chlorella that the first cell cycle after transfer was occupied by adjustments of photosynthesis, of respiration and rates of enzyme accumulation, as cells recovered from the synchronizing regime (John et al., 1981). To avoid such transitional changes, samples for measurement of enzyme activity and protein synthesis were taken in the second cell cycle under constant conditions. The sampling period commenced at $20 \mathrm{~h}$, when a population entirely of daughter cells undergoing release was present, and was completed at $40 \mathrm{~h}$ when these cells had released their daughters (Fig. 7). The sampling period was therefore in phase with that studied in the synchronizing batch culture. The turbidostat culture was maintained at a turbidity $A_{680.1 \mathrm{~cm}}$ of 0.06 (Fig. 5) and this corresponded to the initial culture density in each synchronizing cycle (Fig. 1). At the end of the second cell cycle all the cells released daughters in a period $\left(t_{1}\right)$ of $7 \mathrm{~h}$, between $33 \mathrm{~h}$ and $40 \mathrm{~h}$, and the cycle time $(g t)$ was $19 \mathrm{~h}$. The equation for synchrony index, S.I. $=1-\left(t_{1} / g t\right)$ of Wolosker \& de Almeida (1979) therefore gave a value of 0.63 . It should be noted that synchrony was sharper than the index based upon cell release suggests, since the synchronously formed daughter cells did not immediately separate and there was a random element in their time of rupture of the mother cell wall which prolonged the period of release.

A number of biosynthetic activities became continuous through the cell cycle when synchronizing growth restrictions were lifted. Sulphate uptake increased smoothly through the cell cycle as did the rate of sulphate incorporation into protein (Fig. $3 b$ ). Specific radioactivity remained constant in successive periods of labelling throughout the cell cycle because the $0.83 \mathrm{~mm}$ cold sulphate supplied in the medium considerably exceeded the requirement for growth, and also sulphate levels were maintained by the inflow of fresh medium into the main culture from which samples were taken for pulse labelling. An uptake of less than $3 \times 10^{3}$ c.p.m. per $\mathrm{ml}$ of sub-culture (Fig. $3 \mathrm{~b}$ ) from an available $6.7 \times 10^{5}$ c.p.m. per $\mathrm{ml}$ was observed in each $2.5 \mathrm{~h}$ period, indicating less than $0.4 \%$ consumption. Radioactive sulphate was therefore 


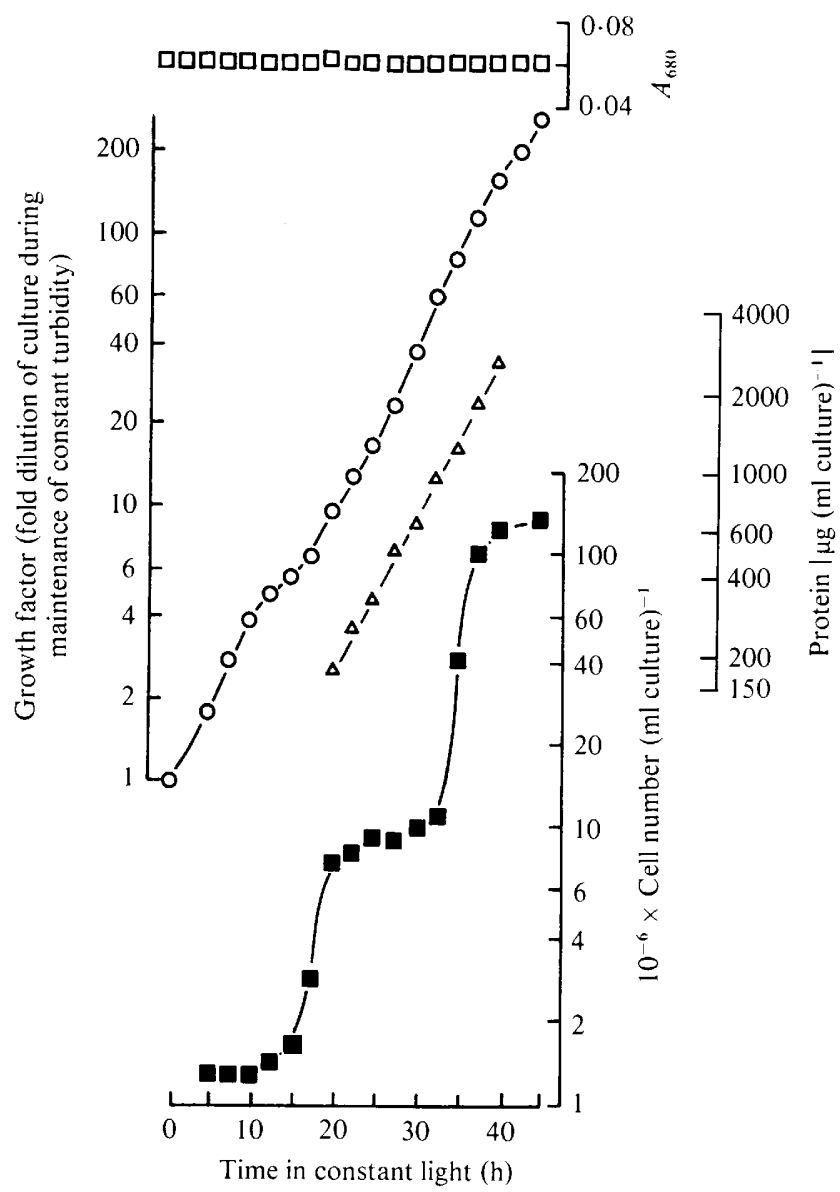

Fig. 7. Growth under constant environmental conditions of continuous illumination and the automatic maintenance of a constant turbidity. Turbidity was measured spectrophotometrically as in Fig. 1 ( $\square$ ). The inflow of fresh medium, which compensated for growth in turbidity of the culture, was continuously monitored and the total extent of dilution was calculated up to each sample time. This value is calculated as increase of turbidity $(O)$ and this growth factor has been allowed for in calculating increase of other parameters. Thus here and in Figs 8 and 3(b), estimates made per ml of culture have been multiplied by the growth factor at time of sampling. The culture was analysed, for total protein $(\triangle)$ and cell number ( $\boldsymbol{\square}$ ), as in Fig. 1. Prior to time 0 the cells had been synchronized by ten cycles of periodic illumination. Two cycles before transfer to turbidostat conditions the cells had been harvested and transferred to low sulphur medium containing $0.07 \mathrm{mM}^{-\mathrm{SO}_{4}}$. Low sulphur medium was used for batch dilution prior to the last synchronizing cycle and throughout the turbidostat culture. Identical timing of cycle events was observed in cells which were maintained in high sulphur medium under the same conditions and used for the study of sulphate uptake and incorporation rates (Fig. $3 b$ ). Carrier free ${ }^{35} \mathrm{SO}_{4}$ isotope giving $0.54 \mu \mathrm{Ci} \mathrm{ml}{ }^{-1}$ was added to the subcultures. The low sulphur medium provided adequate sulphur since growth continued exponentially and, in each of the pulse labelled subcultures, similar proportions of between $45 \%$ and $55 \%$ of the initial radioactivity remained unconsumed at the end of each $2.5 \mathrm{~h}$ period of labelling throughout the experiment.

available at essentially constant specific activity in successive periods of pulse labelling. In preliminary experiments no lag or fluctuation during incorporation into protein was observed. The simplest explanation of the incorporation seen in Fig. 3(b) was that the absolute rate of protein synthesis accelerated through the cell cycle. The constancy of specific incorporation relative to total protein throughout $\mathrm{Gl}, \mathrm{S}$ and $\mathrm{M}$ phases (Fig. $3 b$ ) further indicated that protein synthesis increased exponentially. Protein accumulation (Fig. 7) also increased exponentially 


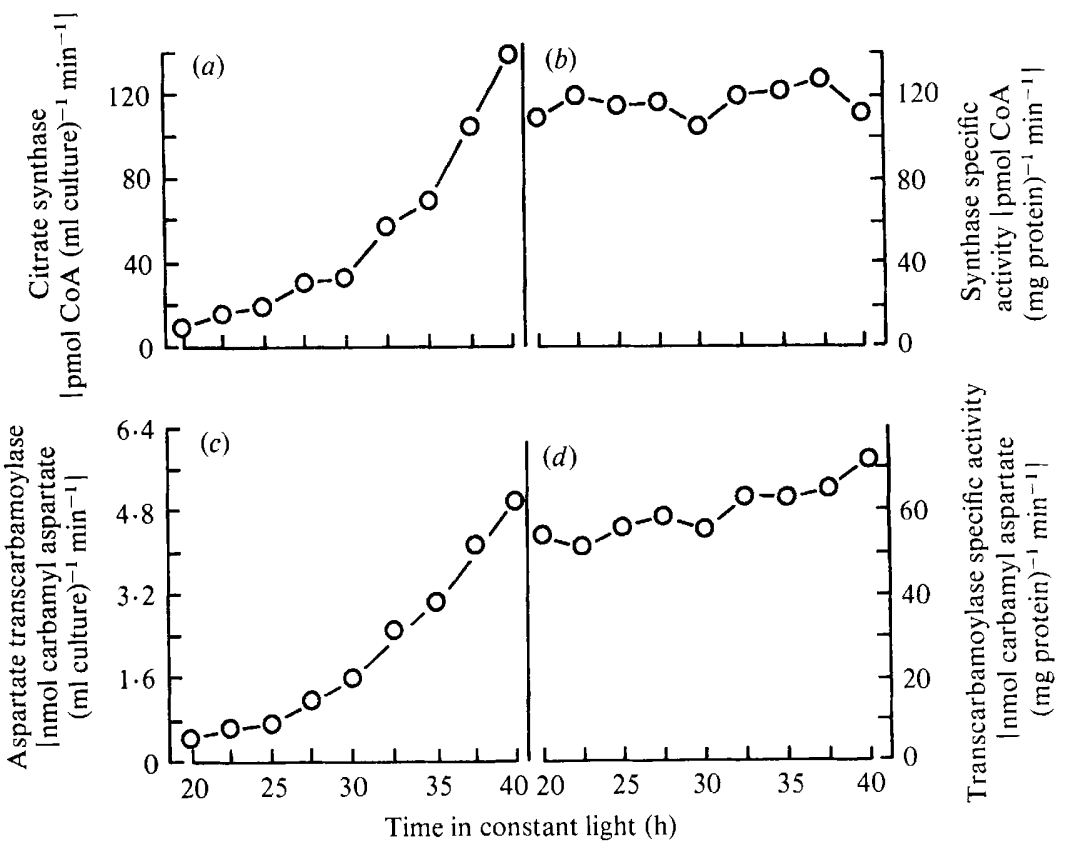

Fig. 8. Enzyme activity accumulated during the second cycle under constant environmental conditions by the cells which are described in Fig. 7. Enzymes were assayed as in Fig. 2 and represented are: $(a)$ citrate synthase activity (ml culture $)^{-1} ;(b)$ citrate synthase specific activity; $(c)$ aspartate transcarbamoylase activity $(\mathrm{ml} \text { culture })^{-1} ;(d)$ aspartate transcarbamoylase specific activity. Specific activities are relative to total protein shown in Fig. 7.

and the correlation with exponential synthesis therefore suggested that there were no phases of rapid protein turnover in mid cycle. There was however a slower increase in turbidity at the time of cytokinesis (Fig. 7) as has been observed in Chlorella (John et al., 1981, 1982).

The turbidostat culture described in Fig. 7 was sampled for the measurement of enzyme activities and to test for rates of individual protein synthesis. The activity of citrate synthase (Fig. 8a) and of aspartate transcarbamoylase (Fig. 8c) increased continuously and at an accelerating rate throughout the cell cycle. Accumulation was approximately exponential and in proportion with the accumulation of other proteins, with the result that the specific activity of these enzymes was essentially constant through the cell cycle under constant environmental conditions (Fig. 8b, d).

The pattern of synthesis of individual soluble proteins through the cell cycle also became continuous following transfer to constant environmental conditions. The numerous changes in rate of incorporation into proteins, which were detected by one-dimensional electrophoresis of protein from batch cultured cells (Figs 4 and 5), were undetectable or substantially reduced when the same procedures were employed with turbidostat grown cells. The soluble proteins (Fig. 9a) showed considerably reduced frequency and extent of changes in rate of synthesis. A few soluble proteins did show changes in rate of incorporation but inspection of autoradiograms showed no instances in which synthesis of any protein became undetectable and the continuous synthesis of all the abundant soluble proteins was also indicated by two-dimensional separation of proteins in these samples, as described below. The sedimentable proteins (Fig. $9 b$ ) also showed a considerable reduction of the profound changes in rate of synthesis that were seen in periodic illumination; however one protein, of mol. wt 70000 showed a cessation of detectable synthesis at $35 \mathrm{~h}$.

To test more rigorously for possible changes in the synthesis of individual proteins, which may have been obscured in one-dimensional separations, two-dimensional fractionation according 
(a)

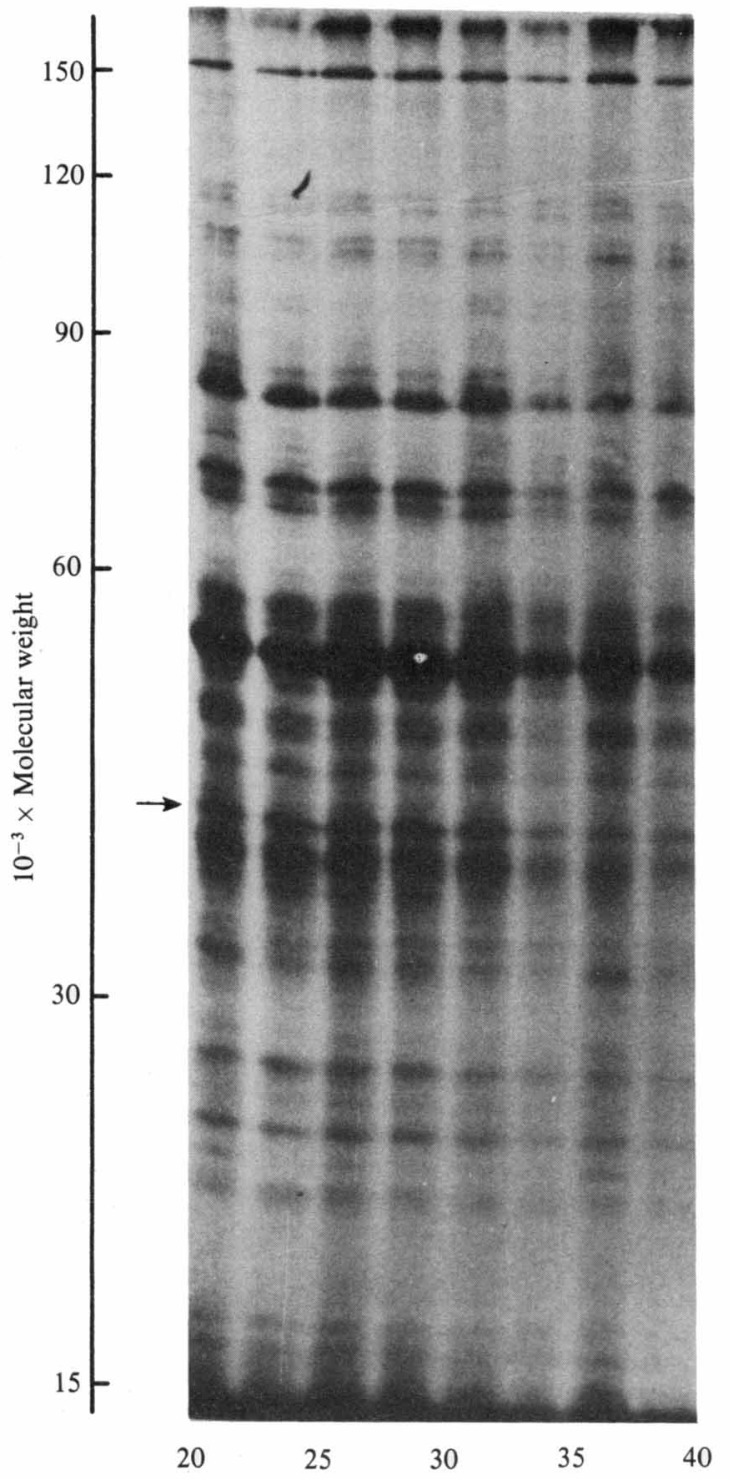

(b)

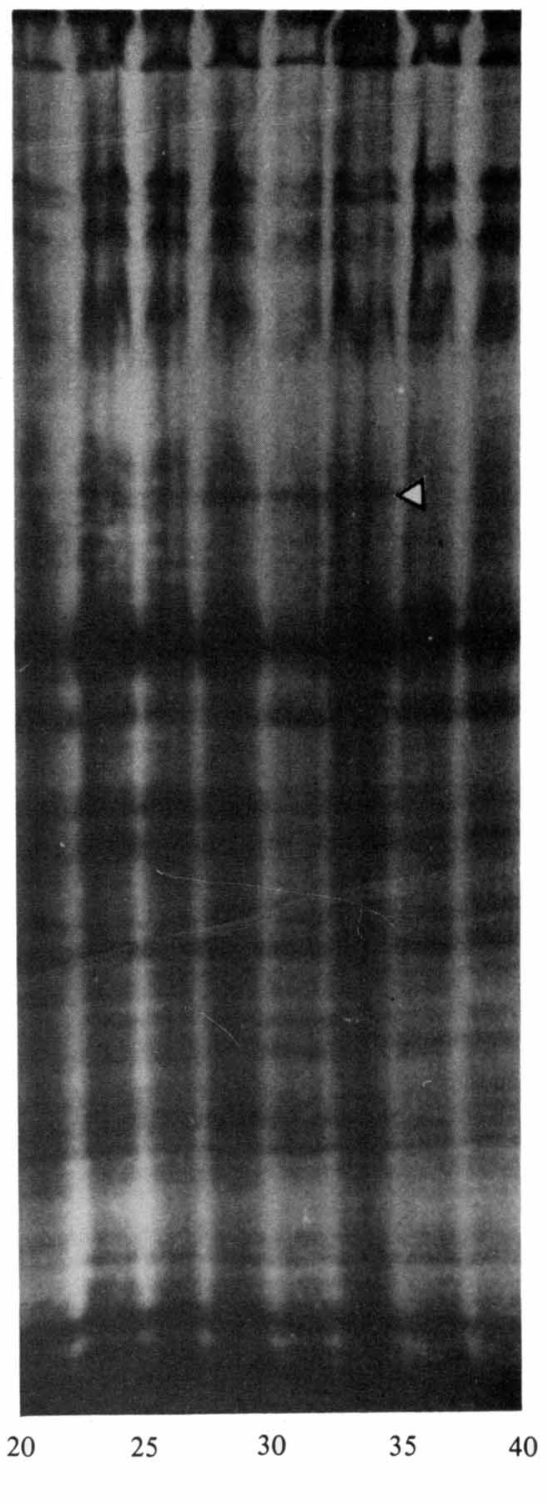

Fig. 9. Proteins in $(a)$ the soluble and $(b)$ the sedimentable fraction, synthesized by cells described in Fig. 7 during their second cell cycle under the constant environmental conditions of turbidostat culture. The cells were synchronized by periodic illumination in batch culture and transferred at time 0 to continuous illumination in turbidostat culture. The cells were in low sulphur medium of $0.07 \mathrm{~mm}-\mathrm{SO}_{4}$ and, for pulse labelling, carrier-free ${ }^{35} \mathrm{SO}_{4}$ giving $0.54 \mu \mathrm{Ci} \mathrm{ml}{ }^{-1}$ was added to cells which had been decanted at $2.5 \mathrm{~h}$ intervals in their original culture medium without interruption of growth and cultured in parallel with the parent culture. After $2.5 \mathrm{~h}$ periods of pulse labelling cells were harvested, smashed and sedimentable and soluble protein fractions were separated by centrifugation at $500000 \mathrm{~g}$ for $20 \mathrm{~min}$. Electrophoresis was performed as described in Figs 4 and 5, and radioactive proteins were detected by autoradiography. A protein which showed a marked decline in rate of synthesis is arrowed.

to O'Farrell (1975) was performed in duplicate on each of the samples seen in Fig. 9(a), i.e. on proteins synthesized throughout the cell cycle. Although more than 300 abundant proteins were resolved by two-dimensional separation of the soluble fraction, when fluorograms were 

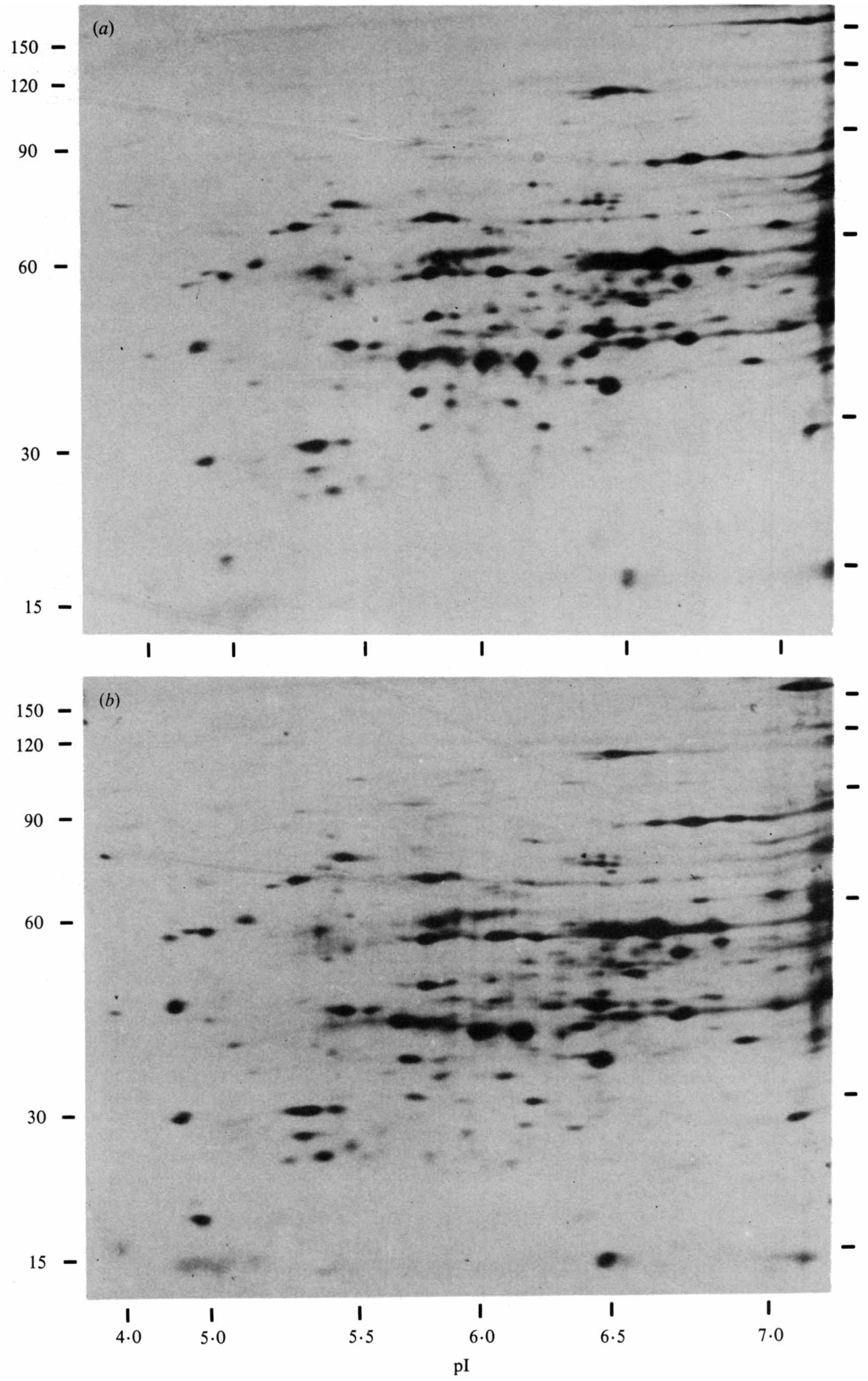
systematically screened using a transparent overlay on which proteins were outlined and numbered, no differences in rate of synthesis of any individual proteins was apparent at any stage of the cell cycle. The similarity of protein populations that were synthesized throughout the cell cycle is illustrated in Fig. 10, which shows soluble proteins synthesized (a) by cells at $25 \mathrm{~h}$ which were in mid G1 phase and were neither carrying out division events nor yet committed to divide and $(b)$ by cells at $35 \mathrm{~h}$ which were actively engaged in the events of mitosis and cytokinesis. Identical populations of the abundant soluble proteins were being synthesized at the two labelling times. There was therefore no evidence that initiation of the synthesis of any abundant soluble protein is necessary for division.

We could not eliminate the possibility that modulations occurred in the rate of synthesis of some proteins because changes in rate of less than twofold were not clearly detected by visual inspection of autoradiograms (Lutkenhaus et al., 1979). However there was evidence that it was uncommon for proteins to show changes in rate of synthesis that approached twofold. Twentyfive proteins, that were resolved by two-dimensional separation of soluble proteins labelled in successive $2.5 \mathrm{~h}$ periods throughout the second cell cycle under turbidostat conditions, were selected as well separated from adjacent proteins but were otherwise chosen at random. When they were excised, solubilized with Packard Soluene 100 and their radioactivity determined, the percentage of total incorporated isotope that resided in each of the individual proteins, after pulse labelling at times throughout the cell cycle, showed a standard deviation of less than $14 \%$.

Proteins in the sedimentable fraction, which were labelled in successive phases throughout the cell cycle (Fig. 10b) were also subject to two-dimensional separation of each sample and although fractionated into more than 200 individual proteins showed no additional evidence of interruptions of synthesis through the cell cycle, other than the single protein of mol. wt 70000 , previously detected in Fig. $9(\mathrm{~b})$, which was seen by two-dimensional separation to have a pI of $6 \cdot 1$ and whose synthesis was confirmed not to continue after $35 \mathrm{~h}$.

Tubulin synthesis in turbidostat cultures

Tubulin synthesis, like that of other abundant soluble proteins became continuous throughout the cell cycle. One-dimensional electrophoresis revealed (Fig. $9 a$ ) that sulphur incorporation into proteins which migrated to the region occupied by tubulin was constant, with neither the higher rate in mid cycle nor the decline during cytokinesis that was seen under synchronizing conditions (Fig. 4). There were no changes in rate of tubulin synthesis masked by overlapping proteins, since two-dimensional separation, which resolved $\alpha$ and $\beta$ subunits of tubulin, revealed similar rates of incorporation into both subunits throughout the cell cycle, as illustrated in Fig. 11 which shows separation of proteins that were synthesized at G1, S, mitosis and cytokinesis phases. Tubulin proteins were identified by inducing tubulin synthesis in vegetative cells that were in early G1 phase under synchronizing conditions and therefore were not appreciably synthesizing tubulin. Pulse labelled proteins in control and in deflagellated cells are seen in Fig. 12. There was a clear induction of two proteins that had pI values of $5 \cdot 4$ and $5 \cdot 6$, identical with those observed by Lefebvre et al. (1980) for tubulins that were identified by immune reaction (Silflow \& Rosenbaum, 1981) and by limited proteolysis (Minami et al., 1981). The $\alpha 3$ (Lefebvre et al., 1980) or af (Brunke et al., 1982) form, into which the $\alpha$ tubulin is post-translationally modified on assembly into flagella, was not detected in Figs 10, 11 and 12, presumably because the modified $\alpha$ form is found exclusively in assembled flagella (Brunke et al., 1982) and these were discarded by centrifugation in the preparation of the soluble fraction prior to electrophoresis.

\section{DISCUSSION}

Under the conventional synchronizing conditions of batch culture with diurnal cycles of illumination and darkness, extensive metabolic changes accompanied the cell cycle in

Fig. 10. Soluble proteins synthesized during periods of pulse labelling in the second cell cycle under constant environmental conditions and separated by two-dimensional isoelectric focusing and electrophoresis. The proteins were those shown in Fig. 9 and illustrated are fluorographs of proteins synthesized $(a)$ in G1 phase, $25-27.5 \mathrm{~h} ;(b)$ in mitosis and cytokinesis phases, $35-37 \cdot 5 \mathrm{~h}$. 
(a)

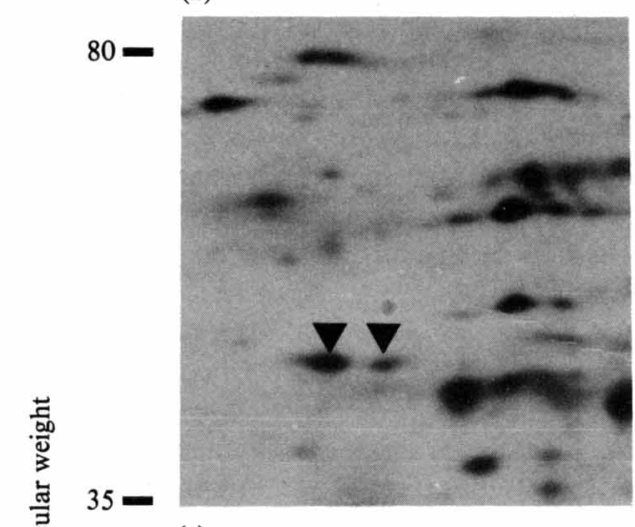

(c)

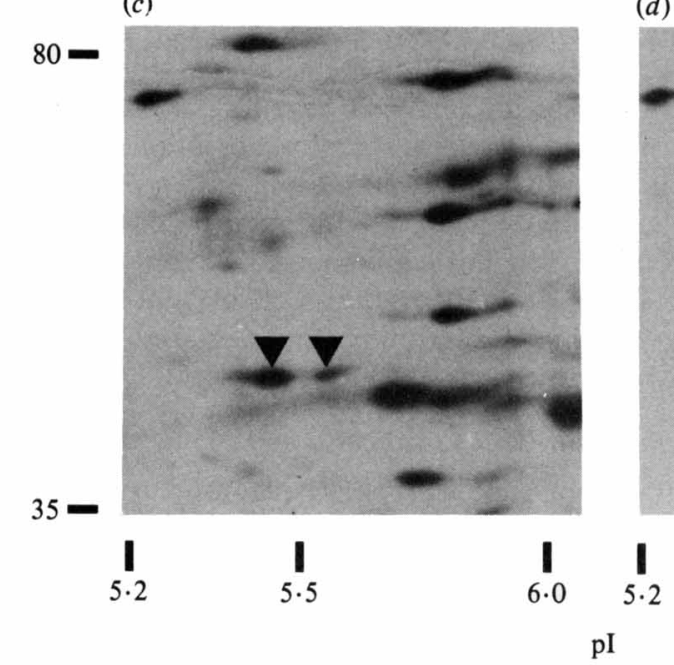

(b)

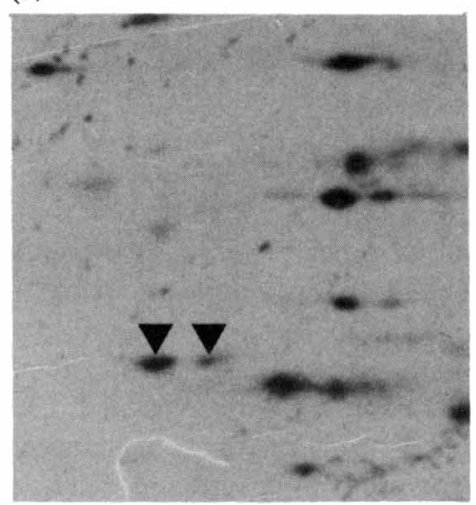

(d)

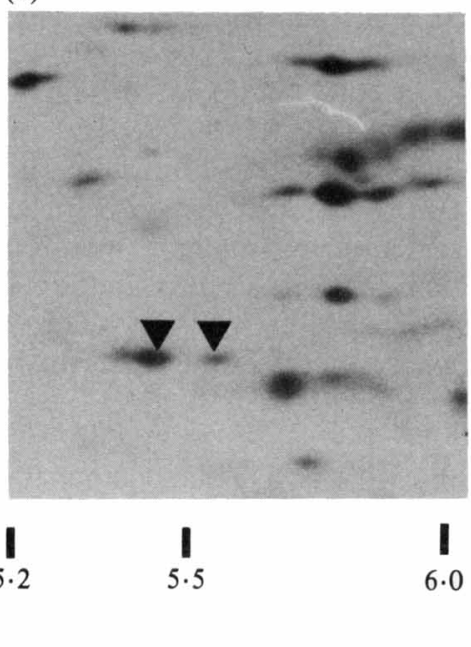

Fig. 11. Soluble proteins synthesized during periods of pulse labelling in the second cell cycle under constant environmental conditions and separated by two-dimensional isoelectric focusing and electrophoresis. The proteins are those shown in Fig. 9 and illustrated are regions of each fluorograph showing proteins of the size and isoelectric $\mathrm{pH}$ range of tubulins. Illustrated, are proteins labelled $(a)$ in $\mathrm{Gl}$ phase, 25-27.5 h; (b) in S phase, 30-32.5 h; $(c)$ in late $\mathrm{S}$ phase and cytokinesis phase, 35-37.5 $\mathrm{h}$; and (d) in cytokinesis phase, $37 \cdot 5-40 \mathrm{~h}$. Tubulins are indicated $(\nabla)$.

Chlamydomonas. There were differences of more than threefold in rate of ${ }^{34} \mathrm{SO}_{4}$ uptake and in rate of incorporation into protein per $\mathrm{ml}$ of culture, and more than 10 -fold changes in the rate of incorporation per amount of protein present (Fig. $3 a$ ). Changes in the rate of synthesis of many individual proteins were apparent throughout the cell cycle (Figs 4 and 5) and there were changes in the rates of increase in citrate synthase activity (Fig. $2 a$ ) and also of aspartate transcarbamoylase (Fig. 2c) as observed by Kates \& Jones (1967). Our data therefore confirm observations of similar changes in protein synthesis by Howell et al. (1977); however differences in growth condition in our study resulted in differences in the times of synthesis and relative abundances of individual proteins.

Comparison with growth in turbidostat conditions provided evidence of the metabolic stress that accompanied the induction of synchronous division. Many fluctuations in biosynthetic activity disappeared under stable growth conditions and the uptake and incorporation of sulphate into total (Fig. 3b) and individual proteins (Figs 9, 10 and 11) and the accumulation of enzyme activities (Fig. $8 a, c$ ) which were seen to fluctuate under synchronizing conditions, 
(a)

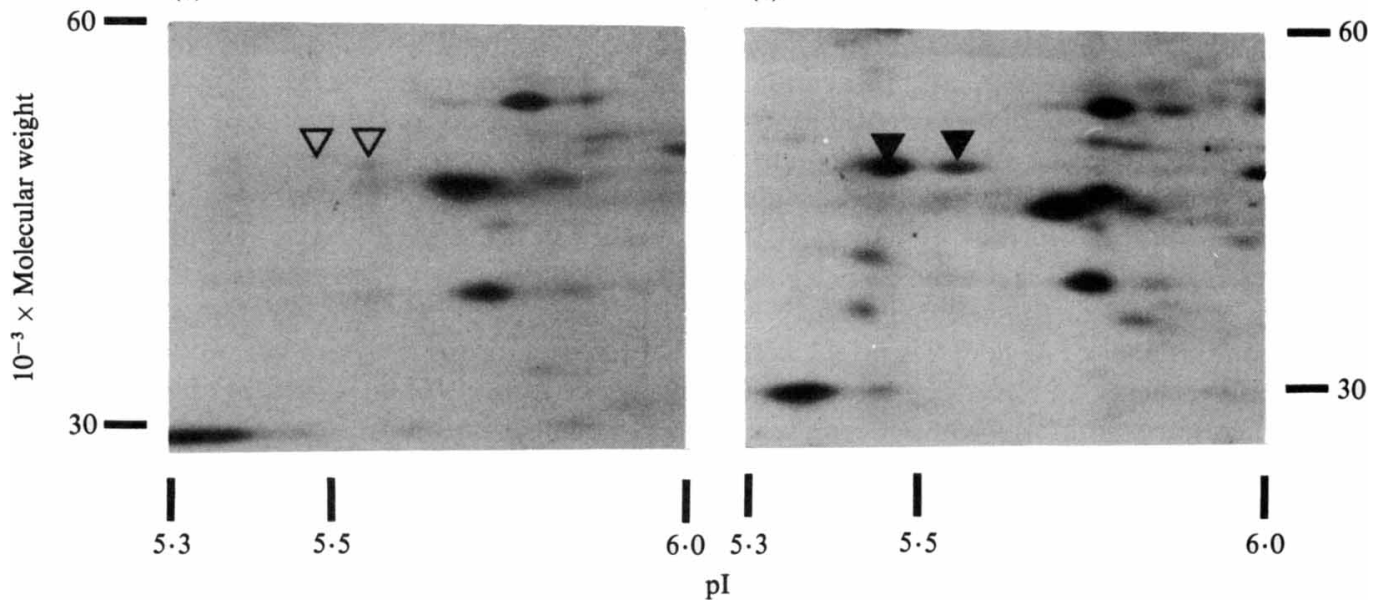

Fig. 12. Tubulin synthesis induced by deflagellation of vegetative cells early in G1 phase under synchronizing conditions. Illustrated are $(a)$ control, non-deflagellated, cells and $(b)$ cells deflagellated prior to provision of ${ }^{35} \mathrm{SO}_{4}$. Tubulins are indicated $(\nabla)$; synthesis not detected $(\nabla)$.

became continuous and were in balance with cell growth (Fig. $3 b$, Fig. $8 b, d$ ). Environmental stress in the synchronizing batch culture regime was also reflected in growth rate and protein content. In the present study cells in batch culture had the same initial turbidity that was maintained in the turbidostat but, due to the limited time for photosynthesis and the increase in mutual shading, the batch grown cells achieved only a sixfold increase in protein during a cell cycle (Fig. 1) compared with a 14-fold increase during the $20 \mathrm{~h}$ period of the second cell cycle in turbidostat culture (Fig. 7). Higher division numbers did occur in the turbidostat culture but there remained a difference in the protein content of the daughter cells under the two culture conditions. Daughter cells produced in the dark phase of synchronizing cultures, and therefore in the absence of concurrent growth, contained only $15 \mathrm{pg}$ protein on average (Fig. 1) while daughter cells produced in the turbidostat under conditions that did not restrict growth, contained on average $25 \mathrm{pg}$ protein (Fig. 7). Similar comparisons of batch and turbidostat cultures of Chlorella revealed that the dark phase of the synchronizing regime caused depletion of starch and a decline in the capacity for respiration. During the illuminated phase of the synchronizing regime there were fluctuations in the rate of both photosynthesis and respiration which did not remain in proportion with cell growth. The perturbations of metabolic processes and enzyme accumulation, persisted through the first cell cycle under constant conditions but a balance between enzyme accumulation, metabolic activity and cell growth was then maintained through subsequent cell cycles (John et al., 1981). Both algae therefore revealed disturbances to metabolism and biosynthetic activity, caused by the starvation that is inherent in the synchronizing regime, and Mitchison (1977) has described similar effects upon enzyme accumulation in Schizosaccharomyces pombe if starvation accompanies the preparation of synchronous cultures.

It is relevant to ask what relationship to the cell cycle there is for the numerous periodic changes in biosynthetic activity that are seen in synchronous cultures under changing environmental conditions. Developmental processes can involve two categories of control (Hames et al., 1972). Primary controls, which regulate essential events in the developmental programme, will be present under all environmental conditions while secondary controls, which have the function of maintaining supplies to the primary processes, may vary with environmental circumstances. In the context of the cell cycle, primary controls will include the still uncertain initiating mechanisms that start events leading to division (reviewed by Donachie, 1981; Fantes \& Nurse, 1981) and dependent primary controls will regulate those biosynthetic activities, such as DNA synthesis that will be necessary in each cycle. 
Primary cell cycle controls were clearly not represented by most of the numerous changes in rate of protein synthesis seen under synchronizing conditions (Figs $3 a, 4$ and 5) because they disappeared under stable environmental conditions (Figs $3 b, 9,10$ and 11). However for the sedimentable protein, of mol. wt 70000 and pI $6 \cdot 1$, whose periodicity of synthesis persisted into the second cell cycle under constant conditions (Fig. $9 b$ ), the pattern may be an essential part of the cell cycle under those conditions, and therefore potentially part of a primary or secondary cell cycle control. Further evidence is necessary to test the alternative possibility that the periodicity was initiated by the earlier synchronizing conditions and was persistent, but was not an essential part of the cell cycle.

Secondary cell cycle controls might be represented among some of the periodic changes in protein synthesis that are seen under synchronizing conditions (Figs 4 and 5). This category would comprise proteins whose periodic synthesis was necessary to sustain events involved in division under synchronizing conditions but not necessary in constant environmental conditions. Tubulin may be an example of such a periodically synthesized protein. In this strain of Chlamydomonas under periodic illumination the intracellular concentration of tubulin has been shown to rise in late $\mathrm{G} 1$ phase, as cells approach DNA synthesis and become committed to divide, and then to fall after $15 \mathrm{~h}$ as cytokinesis events are approaching conclusion (Piperno \& Luck, 1977). The present investigation provided evidence of periodic tubulin synthesis that was consistent with the period of increasing tubulin level (Fig. 4). It remains to be established whether tubulin synthesis itself can act as a molecular switch, upon which mitosis could be dependent under synchronizing conditions. It was, however, clear from our evidence that a periodic increase of $\beta$ tubulin and of the abundant unmodified form of $\alpha$ tubulin was not a necessary event for division under all circumstances, because under constant environmental conditions tubulin synthesis was continuous (Figs 9, 10 and 11). Periodic synthesis of the abundant forms of tubulin was therefore, not part of a primary cell cycle control for spindle and phycoplast formation (Johnson \& Porter, 1968; Pickett-Heaps, 1972).

The periodic synthesis of nearly half of the protein population that was observed under synchronizing conditions (Figs 4 and 5), could not be accounted for by the two categories of primary and secondary cell cycle control. It is not plausible that nearly half of all proteins were directly involved in cell division since the incidence of cell division cycle mutants indicates that less than a tenth of proteins are directly involved in specific division events (Hartwell et al., 1973; reviewed by Pringle, 1981). Among the abundant proteins visualized in Figs 4 and 5, the incidence of proteins directly involved in division was probably even lower than could be expected for the whole protein population, since the abundant soluble proteins would be predominantly enzymes of the major metabolic pathways and the sedimentable fraction comprised largely of membrane proteins involved in processes of cell growth, predominantly chloroplast membrane proteins (Beck \& Levine, 1974; Bourguignon \& Palade, 1976).

A third category of controls must therefore be recognized to accommodate the majority of changes in protein synthesis that accompany the cell cycle only during, or in recovery from, changing environmental conditions. Changing environmental conditions in the synchronizing regime were shown to cause fluctuations in photosynthesis, in respiration and in rate of protein accumulation in Chlorella (John et al., 1981) and were shown here to cause fluctuations in rate of sulphate uptake and incorporation and changes in rate of protein accumulation in Chlamydomonas (Figs 3a, 4 and 5). Synchronizing conditions were therefore seen to impose physiological stress in both intermediary and biosynthetic metabolism.

The correlation seen here between the pattern of enzyme activity and the prevailing pattern of individual protein synthesis is relevant to a discrepancy in the literature concerning enzyme activity and protein synthesis patterns in the cell cycle. Elliott \& McLaughlin (1978) noted that reports of enzyme activity, which were mostly measured in synchronous cultures (reviewed by Halvorson et al., 1971), have indicated a predominantly periodic accumulation through the cell cycle, whereas their observations of individual protein synthesis, made in unperturbed asynchronously growing cells of yeast that were separated by centrifugation into phases of the cell cycle for analysis, showed continuous synthesis of individual proteins. Elliott \& McLaughlin (1978) therefore suggested that a general explanation of the discrepancy might be periodic 
activation of catalytic activity in enzyme proteins. Our present observations allow a simpler explanation since we have shown that the prevailing patterns of enzyme activity and protein synthesis did correlate when both were studied under the same culture conditions and that periodicities in both ceased to accompany the cell cycle under non-perturbing environmental conditions. There is no evidence that periodic increase in enzyme activities and continuous synthesis of proteins commonly occur together. Therefore although enzyme activation may occur in the cell cycle (Mitchelson et al., 1978), there is no necessity to consider large changes in the state of activation to be common among enzymes in proliferating cells.

The possibility remains open that discontinuous synthesis of proteins drives the cell cycle, because we were unable to resolve many proteins: including those that contained no sulphur, those with unusual isoelectric $\mathrm{pH}$ values such as the histones, and the larger number that were present in amounts too small to register. For example, periodic tubulin assembly during the cell cycle may be controlled by ligands or by rates of post-translational modification but it also remains possible that tubulin function is controlled by periodic synthesis of the numerous but quantitatively minor proteins that are associated with structures containing tubulin (Luck et al., 1982).

It is clear however, from the predominance of continuous protein synthesis, that cell cycle controls cannot be part of a general programme of periodic protein synthesis as was envisaged by the theories of linear reading (Halvorson et al., 1971) or oscillatory repression (Donachie \& Masters, 1969). The similarity in this respect between algal cells that divide by multiple fission and a yeast cell that divides by budding (Elliott \& McLaughlin, 1978), suggests that continuous synthesis of the abundant proteins is probably a widespread feature of the eukaryote cell cycle.

Our conclusions also have implications for the use of synchronized algal cultures in studies of organelle development. Batch cultures under periodic illumination are commonly employed to study the assembly of mitochondria (Forde et al., 1976) and chloroplasts (Beck \& Levine, 1974; Bourguignon \& Palade, 1976; Janero \& Barrnett, 1982) and the sequential assembly of components observed under these conditions has been tentatively considered an obligatory part of organelle development and division. The disappearance of periodic synthesis of membrane proteins, of which the chloroplast is the major source, under constant environmental conditions (Fig. $9 b$ ) calls this interpretation into question. Algal cells under synchronizing conditions can provide valuable information concerning organelle assembly during adaptive changes but our present evidence indicates that the sequential events observed are restricted to the synchronizing conditions used and since the diurnal cycle of illumination is their direct cause, they fall into the tertiary category of cell cycle controls, that we have defined above.

The data presented here show how extensive the perturbations of biosynthetic activity in synchronous cultures can be and underline the difficulties of using such cultures to unravel control mechanisms which are specifically essential to the cell cycle. It may be more fruitful to exploit the pioneering work of Howell's group, whose identification of cell cycle genes in Chlamydomonas (Howell \& Naliboff, 1973) opens the way for attempts to identify and to quantify their protein products.

We thank Mr. G. W. McCartney for expert photographic assistance and acknowledge the support of the SERC. M.J.R. and J.D.I.H. also thank the DENI for support.

\section{REFERENCES}

BAum, P., Thorner, J. \& Honig, L. (1978). Identification of tubulin from the yeast Saccharomyces cerevisiae. Proceedings of the National Academy of Sciences of the United States of America 75, 49624966.

BECK, D. P. \& Levine, R. P. (1974). Synthesis of chloroplast membrane polypeptides during synchro- nous growth of Chlamydomonas reinhardtii. Journal of Cell Biology 63, 759-772.

BEST, D., WARR, P. J. \& GULL, K. (1981). Influence of the composition of commercial sodium dodecyl sulfate preparations on the separation of $\alpha$ and $\beta$ tubulin during polyacrylamide gel electrophoresis. Analytical Biochemistry 114, 281-284. 
Bourguignon, L. Y. W. \& Palade, G. E. (1976). Incorporation of polypeptides into thylakoid membranes of Chlamydomonas reinhardtii. Cyclic variations. Journal of Cell Biology 69, 327-344.

Brunke, K. J., Collis, P. S. \& Weeks, D. P. (1982). Post-translational modification of tubulin dependent on organelle assembly. Nature, London 297, 516-518.

COOPER, T. G. \& BeEvers, H. (1969). Mitochondria and glyoxysomes from castor bean endosperm, enzyme constituents and catalytic capacity. Journal of Biological Chemistry 244, 3507-3513.

Donachie, W. D. (1981). The cell cycle of Escherichia coli. In The Cell Cycle, Society for Experimental Biology, Seminar Series vol. 10, pp. 63-83. Edited by P. C. L. John. Cambridge: Cambridge University Press.

Donachie, W. D. \& Masters, M. (1969). Temporal control of gene expression in bacteria. In The Cell Cycle: Gene-Enzyme Interactions, pp. 37-76. Edited by G. M. Padilla, G. L. Whitson \& I. L. Cameron. London: Academic Press.

Donnan, L. \& John, P. C. L. (1983). Timer and sizer controls in the cell cycles of Chlamydomonas and Chlorella. In The Microbial Cell Cycle. Edited by P. Nurse \& E. Streiblova. Boca Raton: CRC Press. (in the Press).

Elliott, S. G. \& Mclaughlin, C. S. (1978). Rate of macromolecular synthesis through the cell cycle of the yeast Saccharomyces cerevisiae. Proceedings of the National Academy of Sciences of the United States of America 75, 4384-4388.

Fantes, P. A. \& Nurse, P. (1981). Division timing: controls, models and mechanisms. In The Cell Cycle, Society for Experimental Biology Seminar Series vol. 10, pp. 11-33. Edited by P. C. L. John. Cambridge: Cambridge University Press.

Forde, B. G., GunNing, B. E. S. \& JoHN, P. C. L. (1976). Synthesis of the inner mitochondrial membrane and the intercalation of respiratory enzymes during the cell cycle of Chlorella. Journal of Cell Science 21, 329-340.

Gerhart, J. C. \& Pardee, A. B. (1962). The enzymology of control by feedback inhibition. Journal of Biological Chemistry 237, 891-896.

Gunning, B. E. S., Steer, M. W. \& Cochrane, M. P. (1968). Occurrence, molecular structure and induced formation of the 'stroma centre' in plastids. Journal of Cell Science 3, 445-456.

Halvorson, H. O., Carter, B. L. A. \& Tauro, P. (1971). Synthesis of enzymes during the cell cycle. Advances in Microbial Physiology 6, 47-106.

Hames, B. D., WeEks, G. \& AshworTh, J. M. (1972). Glycogen synthetase and the control of glycogen synthesis in the cellular slime mould Dictyostelium discoideum during cell differentiation. Biochemical Journal 126, 627-633.

Hansen, J. N., Spiegelman, G. \& Halvorson, H. O. (1970). Bacterial spore outgrowth: its regulation. Science 168, 1291-1298.

Hartwell, L. H., Mortimer, R. K., Culotti, J. \& Culorti, M. (1973). Genetic control of the cell division cycle in yeast. V. Genetic analysis of $c d c$ mutants. Genetics 74, 267-286.

Haselkorn, R., Fernández-Morán, H., Kieras, F. J. \& VAN BRUgGen, E. F. J. (1965). Electron microscopic and biochemical characterisation of fraction 1 protein. Science 150, 1598-1601.

Herbert, D., Elsworth, R. \& Telling, R. C. (1956). The continuous culture of bacteria; a theoretical and experimental study. Journal of General Microbiology 14, 601-622.

Hiller, R. G. \& GoODChILD, D. J. (1981). Thylakoid membrane and pigment organisation. In Photosynthesis, vol. 8 in The Biochemistry of Plants $A$ Comprehensive Treatise, pp. 1-49. Edited by M. D. Hatch \& N. K. Boardman. New York: Academic Press.

HOPKINS, H. A., FloRA, J. B. \& SCHMIDT, R. R. (1972). Periodic DNA accumulation during the cell cycle of a thermophilic strain of Chlorella pyrenoidosa. Archives of Biochemistry and Biophysics 153, 845-849.

Howell, S. H. \& Naliboff, J. A. (1973). Conditional mutants in Chlamydomonas reinhardtii blocked in the vegetative cell cycle. Journal of Cell Biology 57, 760772.

Howell, S. H., Posakony, J. W. \& Hill, K. R. (1977). The cell cycle program of polypeptide labelling in Chlamydomonas reinhardtii. Journal of Cell Biology 72, 223-241.

JANERO, D. R. \& BARRNETT, R. (1982). Thylakoid membrane biogenesis in Chlamydomonas reinhardi $137^{+}$. II. Cell cycle variations in the synthesis and assembly of pigment. Journal of Cell Biology 93, 411416.

John, P. C. L., McCullough, W., Atkinson, A. W. JR, Forde, B. G. \& GunNing, B. E. S. (1973). The cell cycle in Chlorella. In The Cell Cycle in Development and Differentiation, pp. 61-76. Edited by $\mathrm{M}$. Balls \& F. S. Billett. Cambridge: Cambridge University Press.

John, P. C. L., LAMBe, C. A., McGookin, R. \& ORR, B. (1981). Accumulation of protein and messenger RNA molecules in the cell cycle. In The Cell Cycle, Society for Experimental Biology Seminar Series, vol. 10, pp. 185-221. Edited by P. C. L. John. Cambridge: Cambridge University Press.

John, P. C. L., Lambe, C. A., McGookin, R., ORR, B. \& Rollins, M. J. (1982). Poly(A) ${ }^{+}$RNA populations, polypeptide synthesis and macromolecule accumulation in the cell cycle of the eukaryote Chlorella. Journal of Cell Science 55, 51-67.

Johnson, U. G. \& PoRTER, K. R. (1968). Fine structure of cell division in Chlamydomonas reinhardi. Basal bodies and microtubules. Journal of Cell Biology 38, 403-425.

Kates, J. R. \& Jones, R. F. (1967). Periodic increases in enzyme activity in synchronised cultures of Chlamydomonas reinhardtii. Biochimica et biophysica acta 145, 153-158.

KuHL, A. \& LoRenzen, H. (1964). Handling and culturing of Chlorella. Methods in Cell Physiology 1, 159-187.

LAEMMLI, U. K. (1970). Cleavage of structural proteins during the assembly of the head of bacteriophage $T_{4}$. Nature, London 227, 680-685.

LaSKey, R. A. \& Mills, A. D. (1975). Quantitative film detection of $3 \mathrm{H}$ and $14 \mathrm{C}$ in polyacrylamide gels by fluorography. European Journal of Biochemistry 56, 335-341.

Lefebvre, P. A., Silflow, C. D., Wieben, E. D. \& 
Rosenbaum, J. L. (1980). Increased levels of mRNA's for tubulin and other flagellar proteins after amputation or shortening of Chlamydomonas flagella. Cell 20, 469-477.

LIEN, T. \& KNUTSEN, G. (1976). Synchronized cultures of a wall-less mutant of Chlamydomonas reinhardii. Archives of Microbiology 108, 189-194.

LINN, T. \& Losick, R. (1976). The program of protein synthesis during sporulation in Bacillus subtilis. Cell 8, 103-114.

LoRenzen, H. \& Hesse, M. (1974). Synchronous cultures. In Algal Physiology and Biochemistry, pp. 894-908. Edited by W. D. P. Stewart. Oxford: Blackwell Scientific Publications.

Luck, D. J. L., Huang, B. \& Piperno, G. (1982). Genetics and biochemical analysis of the eukaryotic flagellum. Symposia of the Society for Experimental Biology 35, 399-419.

Lutkenhaus, J. F., Moore, B. A., Masters, M. \& DONACHIE, W. D. (1979). Individual proteins are synthesized continuously throughout the Escherichia coli cell cycle. Journal of Bacteriology 138, 352-360.

Minami, S. A., Collis, P. S., Young, E. E. \& Weeks, D. P. (1981). Tubulin induction in $C$. reinhardii: requirement for tubulin mRNA synthesis. Cell $\mathbf{2 4}$, 89-95.

Mitchelson, K., Chambers, T., Bradbury, E. M. \& MatTHEWS, H. R. (1978). Activation of histone kinase in G2 phase of the cell cycle in Physarum polycephalum. FEBS Letters 92, 339-342.

Mitchison, J. M. (1969). Enzyme synthesis in synchronous cultures. Science 165, 657-663.

Mitchison, J. M. (1971). The Biology of the Cell Cycle. Cambridge: Cambridge University Press.

Mitchison, J. M. (1977). Enzyme synthesis during the cell cycle. In Cell Differentiation in Microorganisms Plants and Animals, pp. 377-401. Edited by L. Nover \& K. Mothes. Jena: VEB Gustav Fischer Verlag.

Myers, J. \& ClaRK, L. B. (1944). Culture conditions and the development of the photosynthetic mechanism II. An apparatus for the continuous culture of Chlorella. Journal of General Physiology 28, 103-112.

O'Farrell, P. H. (1975). High resolution two-dimensional electrophoresis of proteins. Journal of Biological Chemistry 250, 4007-4021.

Pickett-Heaps, J. D. (1972). Variation in mitosis and cytokinesis in plant cells: its significance in the phylogeny and evolution of ultrastructural systems. Cytobios 5, 59-77.

PIPERNo, G. \& LUCK, D. J. L. (1977). Microtubular proteins of Chlamydomonas reinhardtii. An immunochemical study based on the use of an antibody specific for the $\beta$-tubulin subunit. Journal of Biological Chemistry 252, 383-391.

Ponstingl, H., Krauhs, E., Little, M. \& KempF, T. (1981). Complete amino acid sequence of $\alpha$ tubulin from porcine brain. Proceedings of the National Academy of Sciences of the United States of America 78, 2757-2761.

Pringle, J. R. (1981). The genetic approach to the study of the cell cycle. In Mitosis/Cytokinesis, pp. 3-28. Edited by A. M. Zimmerman \& A. Forer. New York: Academic Press.

SCHMidT, R. R. (1974). Transcriptional and post-transcriptional control of enzyme levels in eucaryotic microorganisms. In Cell Cycle Controls, pp. 201-233. Edited by G. M. Padilla, I. L. Cameron \& A. H. Zimmerman. London: Academic Press.

Schötz, F., Bathelt, H., ARnold, C.-G. \& SchimMER, O. (1972). Die Architektur und Organisation der Chlamydomonas-zelle. Ergebnisse der Elektronen-mikroskopie von Serienschnitten und der daraus resultierenden dreidimensionalen Rekonstruktion. Protoplasma 75, 229-254.

Silflow, C. D. \& Rosenbaum, J. L. (1981). Multiple $\alpha-$ and $\beta$-tubulin genes in Chlamydomonas and regulation of tubulin mRNA levels after deflagellation. Cell 24, 81-88.

Sueoka, N., Chiang, K.-S. \& Kates, J. R. (1967). Deoxyribonucleic acid replication in meiosis of Chlamydomonas reinhardi. Journal of Molecular Biology 25, 47-66.

SusSman, M. \& BRaCKenbury, R. (1976). Biochemical and molecular-genetic aspects of cellular slime mold development. Annual Review of Plant Physiology 27, 229-265.

Tuchman, J., Alton, T. \& Lodish, H. F. (1974). Preferential synthesis of actin during early development of the slime mold Dictyostelium discoideum. Developmental Biology 40, 116-128.

Valenzuela, P., Quiroga, M., Zaldivar, J., RutTER, W. J., Kirschner, M. W. \& Cleveland, D. W. (1981). Nucleotide and corresponding amino acid sequences encoded by $\alpha$ and $\beta$ tubulin mRNA's. Nature, London 289, 650-655.

WeEks, D. P. \& Collis, P. S. (1979). Induction and synthesis of tubulin during the cell cycle and life cycle of Chlamydomonas reinhardi. Developmental Biology 69, 400-407.

Weingarten, M. D., Suter, M. M., Littman, D. R. \& Kirschner, M. W. (1974). Properties of the depolymerisation products of microtubules from mammalian brain. Biochemistry 13, 5529-5537.

Witman, G. B., Carlson, K., Berliner, J. \& Rosenbaum, J. L. (1972). Chlamydomonas flagella. I. Isolation and electrophoretic analysis of microtubules, matrix, membranes and mastigonemes. Journal of Cell Biology 54, 507-539.

Wollman, F-A., Olive, J., Bennoun, P. \& RecouvREUR, M. (1980). Organisation of the photosystem II centers and their associated antennae in the thylakoid membranes: a comparative ultrastructural, biochemical and biophysical study of Chlamydomonas wild type and mutants lacking in photosystem II reaction centers. Journal of Cell Biology 87, 728-735.

Wolosker, H. B. M. \& de Almeida, D. F. (1979). Quantitative assessment of the synchronization of cell populations. Journal of General Microbiology 110 , 225-227. 